\title{
Geochemistry and geochronology of the shallow-level La Esperanza magmatic system (Permian-Triassic), Northern Patagonia
}

\author{
Carmen I. Martínez Dopico ${ }^{\mathrm{a}, *}$, Mónica G. López de Luchi ${ }^{\mathrm{a}}$, Augusto E. Rapalini ${ }^{\mathrm{b}}$, \\ C. Mark Fanning ${ }^{\mathrm{c}}$, Paul Y.J. Antonio ${ }^{\mathrm{d}}$

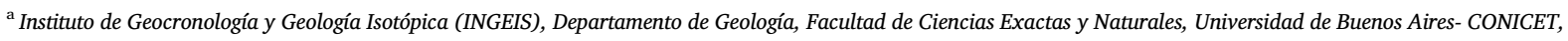 \\ Buenos Aires, Argentina \\ ${ }^{\mathrm{b}}$ Instituto de Ciencias Básicas, Aplicadas y Ambientales de Buenos Aires (IGEBA), Departamento de Geología, Facultad de Ciencias Exactas y Naturales, Universidad de \\ Buenos Aires- CONICET, Buenos Aires, Argentina \\ ${ }^{\mathrm{c}}$ Research School of Earth Sciences, The Australian National University, Mills Road, Canberra, Australia \\ ${ }^{\mathrm{d}}$ Instituto de Astronomia, Geofísica e Ciências Atmosféricas (IAG), Universidade de São Paulo (USP), São Paulo, SP, Brazil
}

\section{A R T I C L E I N F O}

\section{Keywords:}

Patagonia

La Esperanza

Permian- Triassic SLIP

Giménez Granite

$\mathrm{U}-\mathrm{Pb}$ zircon geochronology

\begin{abstract}
A B S T R A C T
The La Esperanza plutonic-volcanic complex is the largest Late Paleozoic-Early Triassic composite magmatic system of northern Patagonia. This paper reports new SHRIMP U-Pb zircon ages and K-Ar muscovite dating as well as whole-rock geochemical data for selected units. In addition, we present some new and reprocessed whole-rock Sr isotopic compositions. On the basis of the new and published data, three compositionally and isotopically distinct high-K magnesian calc-alkaline series were distinguished. Two of these are characterized by high Ba-Sr: (i) biotite and muscovite bearing rhyolites and granites (265 $\pm 2 \mathrm{Ma}$; $260 \pm 2 \mathrm{Ma}$ ) and (ii) metaluminous amphibole-biotite bearing granodiorites (273 $\pm 2 \mathrm{Ma})$, monzogranites (255 $\pm 2 \mathrm{Ma})$, dacites $(253 \pm 2 \mathrm{Ma}$ ), and slightly peraluminous granites (dated herein as $251 \pm 2 \mathrm{Ma}$ ). There is also a low Ba-Sr series of high-silica metaluminous rocks (granites and acid dike swarms; $250 \pm 2 \mathrm{Ma}$ and $\approx 244 \pm 2 \mathrm{Ma}$ ). Geochemistry coupled with geochronology revealed a pulsatory multi-sourced open magmatic system with mafic magma replenishment and reactivation of crystal mushes that occurred before upward migration to upper crustal levels. Mafic magmas alternated with crust-derived magmas incrementally assembled in subvolcanic levels over $30 \mathrm{Ma}$. Zircon crystallization and mica cooling ages in the granite units allowed detection of two magmatic lulls, between 270 and $265 \mathrm{Ma}$ and between 260 and $255 \mathrm{Ma}$. Both episodes coincide with a period of exhumation in upper crustal levels. The new temporal and geochemical constraints allow correlation of the La Esperanza plutonic-volcanic complex with the Los Menucos Group (258-248 Ma), encompassing a volume of magmatism comparable to a moderately sized large igneous silicic province. These mid-to-late Permian to Middle Triassic rocks record the transition between subduction-related magmatism ( $>273 \mathrm{Ma}$ ) and post-orogenic extensional magmatism ( $<250 \mathrm{Ma}$ ) in the Gondwana margin. Even though this magmatism would be coeval with the proposed collision of the Patagonia terrane, no expected syn-collisional magmatism or associated deformation were found in upper crustal levels. However, the different nature and melting conditions of the inferred sources of the magmas that crystallized before $270 \mathrm{Ma}$, between 265 and $260 \mathrm{Ma}$, and from 255 to $245 \mathrm{Ma}$, suggest that the La Esperanza plutonic-volcanic complex was assembled during a 30 Ma period of major plate reorganization.
\end{abstract}

\section{Introduction}

The igneous rocks in the La Esperanza area have received much attention since Ramos (1984) proposed the allochthonous origin of Patagonia. Their isolated location far away from already suspected Paleozoic active margins, the calc-alkaline character of the rocks and alleged Carboniferous ages (subsequently corrected to Permo-Triassic;
Pankhurst et al., 1992) together with the deformation in Late Paleozoic rocks of Sierra de la Ventana, were the three strongest arguments that the rocks in La Esperanza were an active magmatic arc with pre-to syncollisional stages. Pankhurst et al. (2006) proposed that this magmatism was the result of a thermal anomaly in the upper plate (i.e. postcollisional magmatism) postdating the earlier Carboniferous collision of the Deseado Massif and the North Patagonian Massif (Fig. 1a). Recently,

\footnotetext{
* Corresponding author.

E-mail address: carmen.martinez.dopico@gmail.com (C.I. Martínez Dopico).
} 


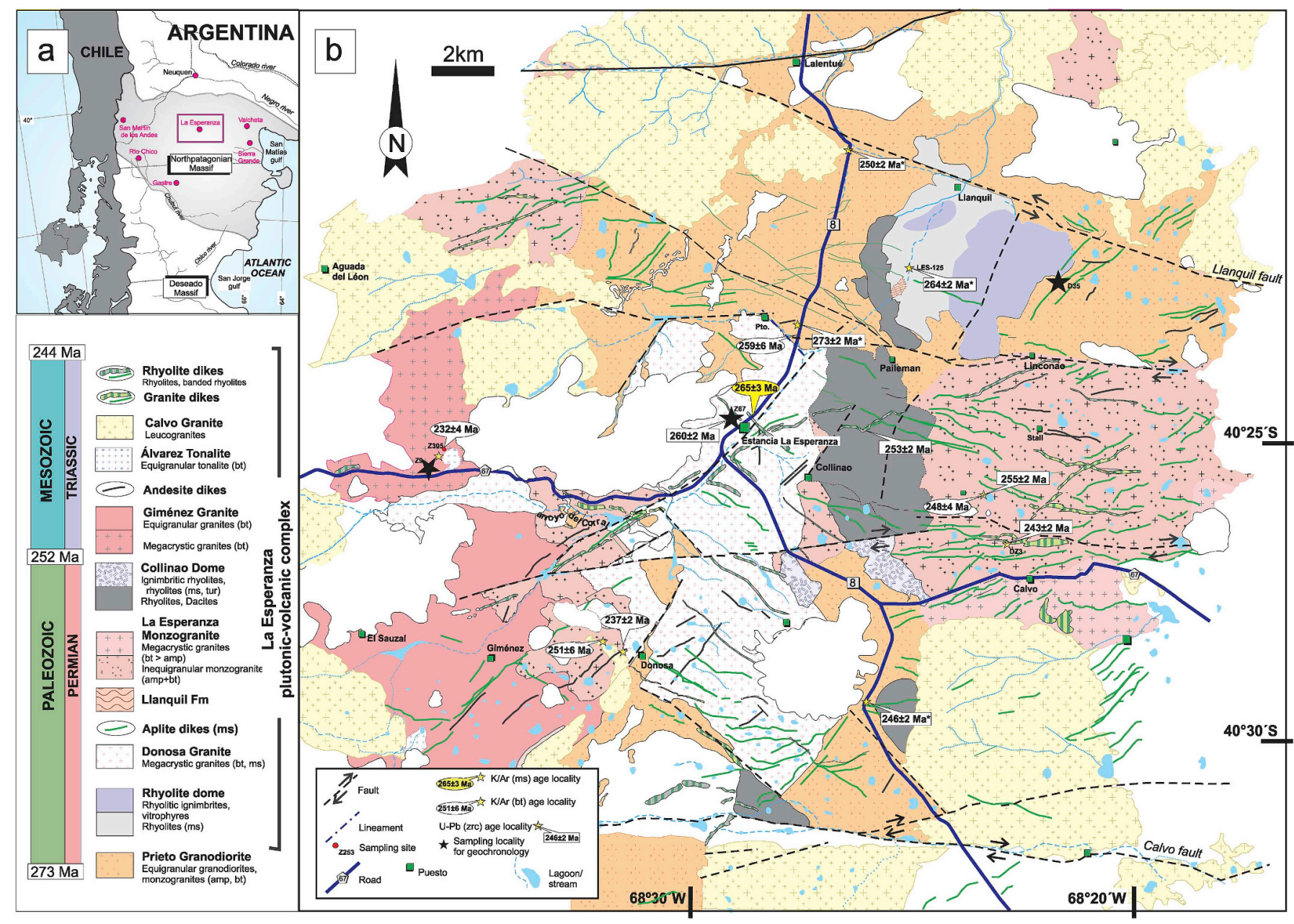

Fig. 1. a) Location of the of La Esperanza area in Northern Patagonia; b) Geological map of the La Esperanza area and surroundings. The yellow stars indicate the localities that were previously dated, as either U-Pb zircon SHRIMP dates or mica K-Ar cooling ages, whereas the black stars show the localities dated in this paper. (For interpretation of the references to color in this figure legend, the reader is referred to the Web version of this article.)

Luppo et al. (2019) found anomalous paleomagnetic pole positions for the 265-252 Ma volcanic rocks around La Esperanza, whereas the paleomagnetic poles of rhyolite dikes dated at $244 \pm 2$ Ma were consistent with the pole position for Middle-Triassic in most reference paths for South America.

The aim of this paper is to present the magmatic stratigraphy, geochronological and geochemical backgrounds of a very well exposed example of a shallow composite magmatic system, the La Esperanza plutonic-volcanic complex of northern Patagonia (Llambías and Rapela, 1984; Martínez Dopico et al., 2013a,b; 2017a), to provide a framework to test future hypotheses regarding the potential cogenetic evolution of the magmas. We report new SHRIMP U-Pb zircon data and two K-Ar muscovite dating as well as WR geochemical data for selected units. In addition, we present some new and reprocessed whole-rock Sr isotopic compositions and review $\mathrm{Hf}$ and $\mathrm{O}$ (in zircon) and whole rock Nd-isotope data published for the area.

\section{Geological background}

The La Esperanza plutonic-volcanic complex crops out in the surroundings of La Esperanza settlement ("Estancia La Esperanza Nueva", 19G 543350 E 5525800 UTM coordinates), in central Río Negro province, Patagonia, Argentina. The Estancia La Esperanza is located $170 \mathrm{~km}$ to the south of Neuquén and $60 \mathrm{~km}$ to the north of Los Menucos (Fig. 1a). Permian to Triassic igneous rocks are distributed in an area of over $1000 \mathrm{~km}^{2}$ (conservatively), although recent regional correlations
(Luppo et al., 2018, 2019) suggest that the magmatic event could have extended over more than $3000 \mathrm{~km}^{2}$ beneath large areas covered by the Cenozoic Somun Curá volcanic plateau.

The geology of the La Esperanza area was described in detail by Llambías and Rapela (1984) who proposed the terms "La Esperanza plutonic complex" and "Dos Lomas volcanic complex" to distinguish the plutonic suites from the volcanic and volcaniclastic rocks, subvolcanic leucogranites and dikes. These complexes were thought to be separated by a regional unconformity. This former stratigraphy, followed by Cucchi et al. (2001), was modified by Martínez Dopico et al. (2013b) with the hypothesis of a single magmatic plumbing system built by the assembly of magma batches and termed it the La Esperanza plutonicvolcanic complex. Rapela and Llambías (1985) and Martínez Dopico et al. (2013a,b, 2014 studied the geochemistry of the pre-Jurassic units, describing a meta-to slightly peraluminous, magnesian, high-K calcalkaline granite series that evolved through a combination of processes such as mixing and fractional crystallization of magmas from at least two different sources (Martínez Dopico et al., 2013a,b).

The first reliable time constraints for these rocks were established with WR Rb-Sr isochrons yielding late Permian to Middle Triassic ages (Pankhurst et al., 1992), superseding previous mistaken Carboniferous ages. U-Pb zircon crystallization ages were provided by Pankhurst et al. (2006), and after by Martínez Dopico et al. (2017b) and Luppo et al. (2019). Together with thermochronological data (Martínez Dopico et al., 2013a,b; 2017b), mica cooling ages bracketed the evolution of the rocks between mid-Permian (Kungurian-Roardian) and Middle 
Triassic (Anisian). Sm-Nd, Lu-Hf and O isotopic data are available from Pankhurst et al. (2006), Fanning et al. (2011) and Castillo et al. (2017).

\section{La Esperanza plutonic-volcanic complex}

The exposures of igneous rocks around Estancia La Esperanza cover an area larger than $2500 \mathrm{~km}^{2}$, where mid-Permian to Middle Triassic intrusions and associated volcanic products were mapped as La Esperanza plutonic-volcanic complex (LEPVC) (Fig. 1b). The intrusive rocks of the LEPVC crop out as small scattered and flat bodies, whereas the volcanic and subvolcanic counterparts constitute a dome (known as a rhyolite dome in Llambías and Rapela, 1984), and a large mostly eroded plain (Fig. 1b). These rocks are intruded by several generations of large super-acidic dike swarms and leucogranite plugs that stand out above the regional topography as ridges. Volcanic rocks are distributed along a N-S elevated axis that extends $45 \mathrm{~km}$ to the south, from the puesto Llanquil to the Piche Graben (outside our area of interest). Spatial distribution is affected by E-W transform faults (Giacosa et al., 2007). The regional host rocks of the LEPVC are the Early Paleozoic phyllites and quartzitic schists of the Colo Niyeu Formation (Labudía and Bjerg, 1994; Martínez Dopico et al., 2017), which are intruded by the oldest unit of the complex, the Prieto Granodiorite, $30 \mathrm{~km}$ to the SW of Estancia La Esperanza.

The geochemical data provided in this paper is a compilation of the whole-rock major and minor elements of Rapela and Llambías (1985), major, minor and trace elements of Martínez Dopico et al. (2013a,b), mineral chemistry of Martínez Dopico et al. (2013a) and new data representative of the main units of the LEPVC.

\subsection{Intrusive units}

Geochemical and field data allow recognition of four main mappable units among the subvolcanic intrusions: 1) Prieto Granodiorite; 2) Donosa Granite and muscovite-bearing aplite dikes; 3) La Esperanza Monzogranite; and 4) Giménez Granite (Fig. 1b).

\subsubsection{Prieto Granodiorite}

This unit crops out to the north and south of the Estancia La Esperanza and its surrounding areas (Fig. 1b) and partially corresponds to Prieto Granodiorite of Llambías and Rapela (1984). The granodiorite dated at $273 \pm 2$ Ma by Pankhurst et al. (2006) belongs to this unit. The granodiorite bodies were emplaced as large horizontal layers in the border of the complex or as N-S aligned vertical feeders (magma conduits, see Martínez Dopico et al., 2017a). The Prieto Granodiorite is in fault contact with the Donosa Granite and is covered by younger volcanic and subvolcanic rocks to the east of Estancia La Esperanza. Biotite-amphibole granites, granodiorites and minor diorites (modal classification) displaying a wide range of textures and compositions make up the Prieto Granodiorite $\left(63-70 \% \mathrm{SiO}_{2} ; 3<\mathrm{K}_{2} \mathrm{O}<4 \%\right.$; $\mathrm{MgO}>2 \%$; $0.84<$ ASI $\left.<0.93 ; \mathrm{La} / \mathrm{Yb}{ }_{\mathrm{N}} \approx 13\right)$. The rocks are dominantly dark grey, ferromagnetic $\left(10^{-2} \mathrm{SI}\right)$ and exhibit medium-grained equigranular textures with variable modal contents of mafic minerals (Fig. 2a). They are characterized by euhedral zoned plagioclase (cores $\mathrm{An}_{45-55}$ to rims $\mathrm{An}_{20-25}$; see details in Table 6 Supplementary data) (30-35\% modal) together with magnesian hornblende (8-15\%) and biotite $(10 \%)$ clots, each of similar size, embedded in K-feldspar (20-30\%) and anhedral quartz (20-25\%) pools. Pyroxene was occasionally observed as cores of amphibole, particularly in coarse-grained microgranular mafic enclaves. Apatite, zircon, magnetite and titanite are accessory minerals.

\subsubsection{La Esperanza monzogranite}

This is a composite pluton that covers half of the studied area. Based on its texture, type of magmatic enclaves, magnetic susceptibility and age, the monzogranites and granites are distinguished from the original "Prieto Granodiorite" of Llambías and Rapela (1984). Two granitoid facies with transitional contacts were recognised; the most extended facies is inequigranular, whereas the other encompasses porphyritic granites and crops out exclusively around puesto Calvo. The inequigranular facies crops out in the easternmost sector of La Esperanza as a subhorizontal layer or sill, whereas in the west, the spatial distribution of its outcrops reflects the NNW-SSE and NW-SE anisotropies of the basement (Martínez Dopico et al., 2017a). This facies comprises grey, variably ferromagnetic $\left(10^{-3}-10^{-2} \mathrm{SI}\right)$, inequigranular granodiorites and monzogranites $\left(63-68 \% \mathrm{SiO}_{2} ; 3<\mathrm{K}_{2} \mathrm{O}<4 \%\right.$; $\mathrm{MgO}<$ $2 \% ; 0.90<$ ASI $<1.13 ; 20<\mathrm{La} / \mathrm{Yb}_{\mathrm{N}}<30$ ) in which euhedral plagioclase (or K-feldspar) is embedded in a matrix of granitic composition. It is characterized by euhedral zoned plagioclase (cores An35-45 to rims An20-25; Table 6 Supplementary data, 30-45\% modal), euhedral biotite and $\mathrm{Mg}$-hornblende clots (color index $<18 \%$ ), poikilitic filiform perthitic K-feldspar (20-30\%) and anhedral quartz (20-30\%). Allanite, zircon and titanite are accessory minerals. In the Arroyo del Corral (Fig. 1b), the inequigranular monzogranites of La Esperanza are observed intruding the Donosa Granite. Close to puesto Calvo, K-feldspar megacrysts are developed, amphibole disappears and the color index drops to $<5 \%$ (porphyritic granite; 68-71\% $\mathrm{SiO}_{2}$; $3<\mathrm{K}_{2} \mathrm{O}<4 \% ; \mathrm{MgO}<1.2 \% ; 0.9<\mathrm{ASI}<1.0 ; \mathrm{K} \approx 10^{-3} \mathrm{SI}$ ), and porphyritic microgranular mafic enclaves are also present (Fig. 2b). In the field, these granitoids are isotropic. However, in several localities north of puesto Donosa and to the east of puesto Linconao very finegrained rocks exhibit macroscopic magmatic foliation due to a weak shape-preferred orientation of ferrosilicates or plagioclase crystals: in such rocks, the color index rises to $25 \%$. Rounded mafic microgranular enclaves are very abundant and display two types: (i) up to $15 \mathrm{~cm}$ long rounded and very dark, porphyritic (plagioclase) enclaves (Fig. 2b) and (ii) small fine-grained equigranular enclaves. The mineralogical composition of the enclaves is identical to that the host. The inequigranular monzogranite facies was dated as $255 \pm 2 \mathrm{Ma}$ using U-Pb SHRIMP methodology on magmatic zircons (Martínez Dopico et al., 2017a). This age agrees with $\mathrm{K}-\mathrm{Ar}$ mica cooling ages and stratigraphic relations (Fig. 1b); see Martínez Dopico et al. (2017b) for further discussion.

\subsubsection{Donosa Granite}

This unit is the core of the complex. It crystallized at $260 \pm 2 \mathrm{Ma}$ (Martínez Dopico et al., 2017a) and comprises a pink euhedral K-feldspar megacrystic granite. Its discontinuous outcrops describe a large NS elongated body with NW-SE and SW-NE, fault-related, rectilinear borders. Several E-W and SW-NE dextral faults dismember the pluton and there are isolated outcrops along the E-W and NE-SW valleys to the west of Estancia La Esperanza. The Donosa Granite is in fault contact with the Prieto Granodiorite in its northern and western margins and it is covered by the Collinao Dacite to the east. Donosa granites exhibit oversized pink euhedral K-feldspar megacrysts up to $15 \times 4 \mathrm{~cm}$. Field measurements indicate a dominant NNW-SSE orientation of megacrysts with a slight NW plunge. Excluding this magmatic lineation, the main $\mathrm{N}-\mathrm{S}$ body is mostly isotropic. However, along the Arroyo del Corral valley, locally ductile magmatic shear bands and porphyritic synmagmatic dikes are common. These bands are defined by the alignment of biotite and pseudotachylite material that crosscut the rock and create areas of orthogneiss. Some K-feldspar megacrysts display a domino alignment when associated with shear band sense of movement. These deformational features were usually detected close to the contact with the more dioritic components of the Prieto Granodiorite. Other evidence of brittle and ductile deformation such as autobrecciation and development of decimetric zones of orthogneiss were found. Finegrained pink muscovite-bearing leucogranite dikes are associated with this unit (e.g. sample DZ35a; Table 3).

The most outstanding feature of the Donosa granites $\left(\mathrm{K} \approx 10^{-3}\right.$ $10^{-4} \quad \mathrm{SI} ; \quad 71-76 \% \quad \mathrm{SiO}_{2} ; \quad 3.4<\mathrm{K}_{2} \mathrm{O}<4.3 \% ; \quad \mathrm{MgO}<1 \%$; $0.95<$ ASI $<1.10$ ) is the presence of oversized K-feldspar megacrysts. They occur as euhedral perthitic microcline locally showing macroscopic Carlsbad twinning, sodium-rich rims and poikilitic inclusions of 

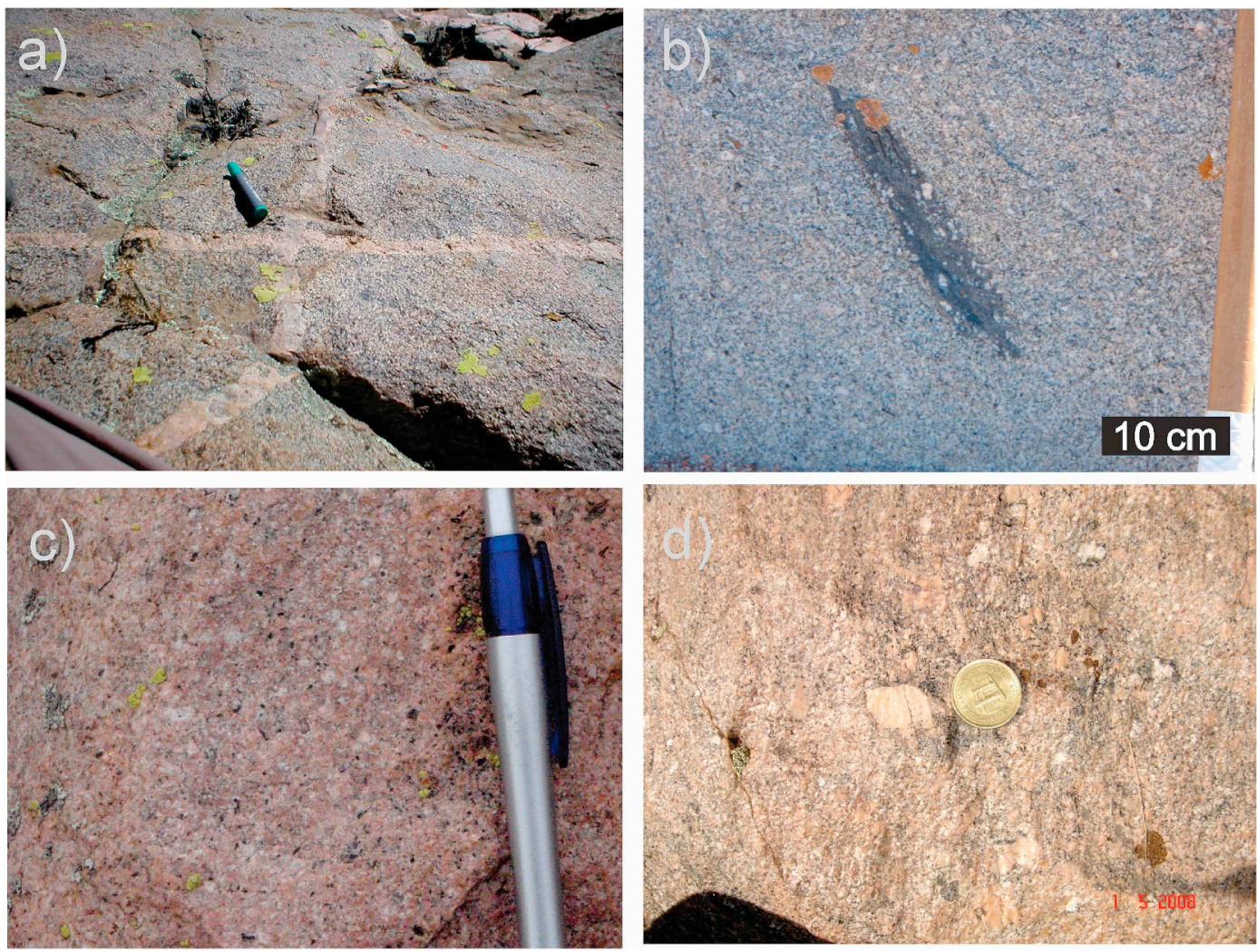

Fig. 2. Plutonic units of the LEPVC a) Prieto Granodiorite at locality 19G $539094 \mathrm{~m}$ E, $5524100 \mathrm{~m}$ S, note the absence of enclaves; b) Plagioclase porphyritic magmatic microgranular enclave in La Esperanza granodiorites at $539934 \mathrm{~m} \mathrm{E,} 5521493 \mathrm{~m} \mathrm{~S}$; c) Giménez Granite (equigranular texture) in the locality type, nearby puesto Giménez (536362 m E, $5519878 \mathrm{~m} \mathrm{S);} \mathrm{d)} \mathrm{Megacrystic} \mathrm{facies} \mathrm{of} \mathrm{Giménez} \mathrm{granites} \mathrm{in} \mathrm{the} \mathrm{locality} \mathrm{dated} \mathrm{herein} \mathrm{(534601} \mathrm{m} \mathrm{E,} 5525913 \mathrm{~m} \mathrm{~S}$ ). Donosa Granite and Calvo Granite are not shown here; the reader is referred to Martínez Dopico et al. (2017a).

quartz. The matrix is monzogranitic and displays equigranular coarseto-medium grained texture that consists of quartz (20-30\% modal), plagioclase (30-40\%), perthitic microcline (25-35\%) and biotite ( $<10 \%$ modal). Apatite, zircon, monazite, magnetite and muscovite (along borders and cleavage traces of biotite) are accessory minerals. Plagioclase crystals are mostly subhedral, complexly twinned, and show zoning from core $\left(\mathrm{An}_{30-20}\right)$ to rim $\left(\mathrm{An}_{20-15}\right)$ (Table 6 Supplementary material). Quartz crystals are subhedral to anhedral, normally forming interstitial clusters and sometimes develop parallel subgrains and chessboard patterns. Biotite is subhedral and greenish-brown, locally intergrown with magnetite. Magnetite is mostly euhedral and free of alteration, although in some sampling sites hematite replacement is widespread. Tourmaline traces were found where decimetric magmatic shear zones develop. Except for local deformation along the E-W Arroyo del Corral, the overall magmatic texture remains unmodified. The transition to the dominant undeformed rock is sharp. In outcrop scale subrounded granite biotite-rich clots occasionally appear. Well-rounded microgranular granodiorite enclaves are rare.

\subsubsection{Giménez Granite}

This unit crops out to the north of the puesto Giménez area and shows transitional contacts with the inequigranular monzogranites of the La Esperanza Monzogranite. It is typically a fine-grained equigranular pink to pinkish grey granite $\left(70-76 \% \mathrm{SiO}_{2} ; 3<\mathrm{K}_{2} \mathrm{O}<5 \%\right.$; $\mathrm{MgO}<1 \% ; 0.90<\mathrm{ASI}<1.15$ ) (Fig. 2c). A geochemical transition between these two units was proposed by Rapela and Llambías (1985). Rocks are slightly ferromagnetic $\left(\mathrm{K} \approx 10^{-3}-10^{-4} \mathrm{SI}\right)$. Close to the puesto Giménez, the granite contains K-feldspar (30-40\%), plagioclase (25-35\%) and quartz (25-30\%) with variable amounts of biotite (5-15\%). Magnetite, apatite, zircon and scarce monazite are accessory minerals. K-feldspar is euhedral, characteristically zoned and perthitic.
Plagioclase crystals are subhedral and zoned, with core composition ranging from $\mathrm{An}_{42}$ to $\mathrm{An}_{38}$ and strongly sodic rims ( $<\mathrm{An}_{10}$ ), sometimes myrmekitic. Quartz is anhedral and exhibits low-to-medium temperature deformation features such as chessboard extinction, subgrain development and bulging structures. Biotite is subhedral, brown-yellow colored. In the field, these granites are mostly isotropic, although NWSE $\left(130-150^{\circ}\right)$ trending magmatic foliation with variable dip was observed in a few localities.

Further north of the puesto Giménez, around Ruta Nacional 67, the granite develops a porphyritic texture with K-feldspar megacrysts up to $12 \mathrm{~cm}$-long embedded in a granite matrix (megacrystic granite facies; Fig. 2d). The matrix is composed of K-feldspar, plagioclase, quartz, biotite, minor quantities of muscovite and accessories such as zircons, magnetite and apatite. The K-feldspar megacrysts are euhedral and locally exhibit shadow tails. They are inhomogenously distributed but locally concentrated with their major axes defining steep lineations. Kfeldspar megacrysts are thought to concentrate through mechanical accumulation during constricted magma flow in pipes (Paterson et al., 2005). Flattened equigranular biotite rich-schlieren and plagioclase aggregates up to $10 \mathrm{~cm}$ are abundant. The schlieren consist mostly of biotite and andalusite (plus cordierite) surrounded (replaced) by muscovite (chlorite). Andalusite might be considered as a restitic or peritectic phase whereas individual crystals of euhedral biotite apparently crystallized from the melt. Foliated metamorphic enclaves are also observed. Further northeast, these rocks are transitionally interfingered with a grey banded porphyritic muscovite-biotite granodiorite in synmagmatic folds. The attitude of these banded rocks is NNW-SSE, dipping to the west. The megacrystic granites are sharply interlayered and intruded by a grey biotite-bearing tonalite (herein named Álvarez Tonalite; $66-70 \% \mathrm{SiO}_{2} ; 2<\mathrm{K}_{2} \mathrm{O}<3 \%$; $\mathrm{MgO}<2 \% ; 1.03<$ ASI $<1.12$ ) in which magmatic foliation is depicted by the alignment of plagioclase 

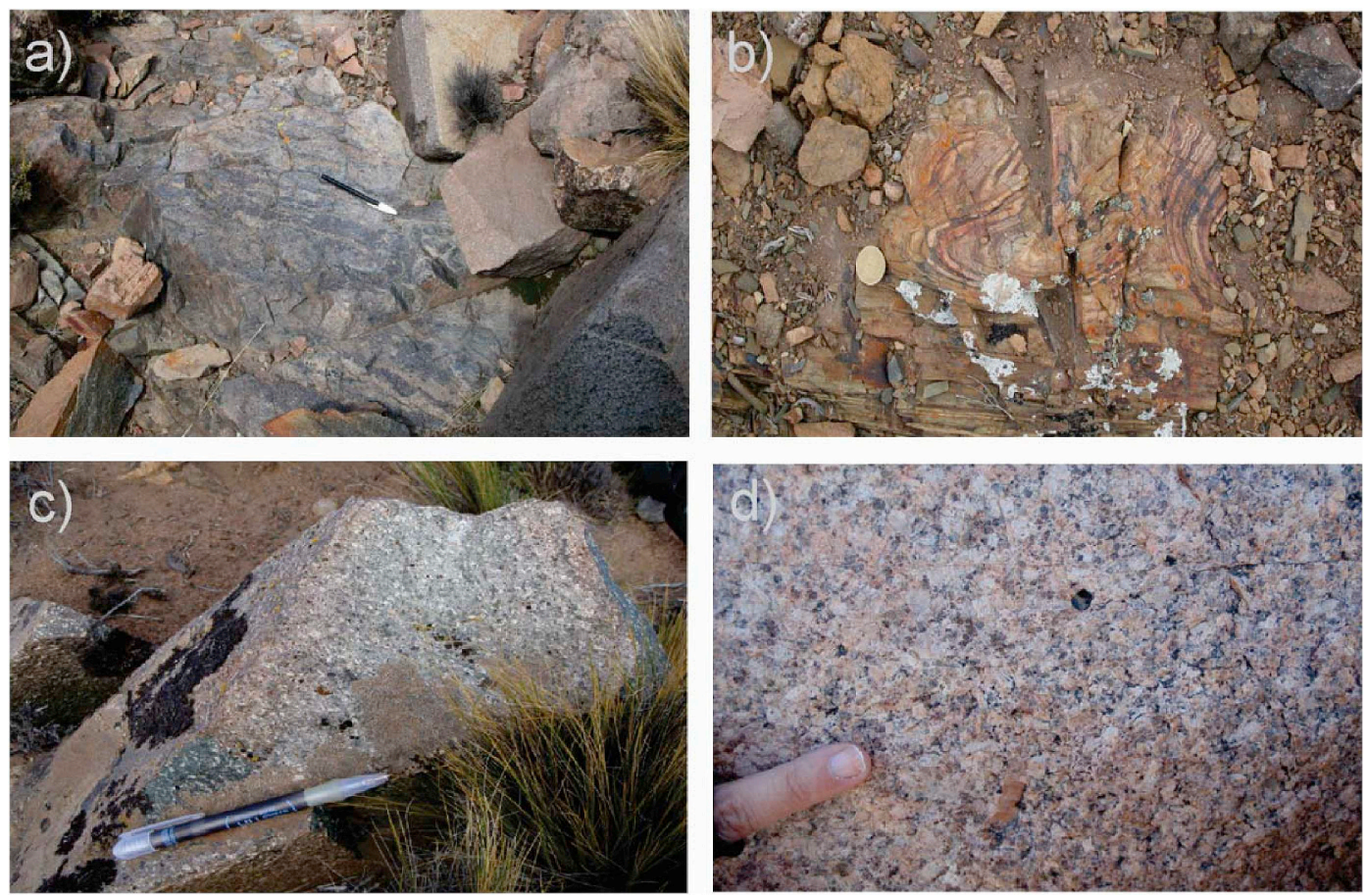

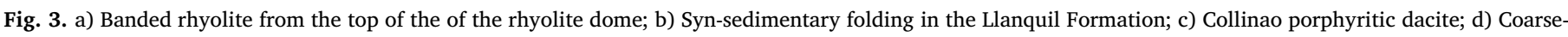
grained leucocratic Calvo granites in the surroundings of puesto Calvo (see Fig. 1b).

crystals.

\subsection{Extrusive units}

Among (semi)extrusive rocks formerly known as the Dos Lomas plutonic-volcanic complex (Llambías and Rapela, 1984), seven units have been distinguished: 1) Pailemán Rhyolite composed of rhyolite, ignimbritic rhyolite and vitrophyre, 2) Pailemán breccias, and 3) Llanquil Fm. making up the rhyolite dome; 4) andesite dikes; 5) Collinao Dacite made up of (a) ignimbritic dacite and rhyodacite, and (b) dacite; 6) Calvo Granite; and 7) Acidic dikes of (a) aplite and leucogranite and (b) porphyritic rhyolite (Fig. 1b).

\subsubsection{Pailemán Rhyolite and related lithologies}

The Pailemán Rhyolite crops out in the central to northern parts of a dome-shaped body (the "rhyolite dome" of Llambías and Rapela, 1984) ca. $8 \mathrm{~km}$ northeast of Estancia La Esperanza. The unit corresponds to the mid and upper sections of high-viscosity rhyolitic lava plugs and black and purple vitrophyres (Fig. 3a). The Pailemán rhyolites are porphyritic with a high proportion of phenocrysts to matrix. They consist of subhedral to anhedral quartz, subhedral and partially broken crystals of zoned plagioclase, variable amounts of K-feldspar, muscovite, ferromagnesian minerals (biotite) and opaque minerals set in a devitrified groundmass. Feldspar phenocrysts are perthitic and partially replaced by sericite and clay minerals whereas ferromagnesian minerals are replaced by chlorite aggregates. A representative rock of the rhyolite dome, a muscovite-bearing rhyolite was dated with U-Pb SHRIMP zircon data at $264 \pm 2 \mathrm{Ma}$ (Pankhurst et al., 2006).

The Llanquil Formation is an epiclastic volcanic microbreccia (Fig. $3 \mathrm{~b}$ ) associated with the volcanic dome that comprises a series of very small outcrops in the western slope of the southernmost part of a SSE-NNW valley that dissects the Pailemán dome. It is crosscut by felsic microgranite dikes.

In the eastern part of the rhyolite dome, an autoclastic rhyodacitic breccia (herein called Pailemán Breccia) overlies the Prieto Granodiorite. It is a porphyroclastic rock with a high proportion of phenoclasts to matrix $(>60 \%$ ) which shows several episodes of brecciation. Phenoclasts show great variation in size, reaching up to a centimetre; the phenoclastic fraction is composed of mainly subhedral rounded and partially broken quartz and subhedral non-zoned plagioclase, biotite (their proportions are widely variable) and very minor amount of opaque minerals. Alteration is pervasive and mainly affects plagioclase and biotite. Secondary muscovite was seen. The groundmass is inhomogeneous showing different degrees of crystallinity with perlitic, felsitic and microgranular textures. There are amphibole bearing-xenoliths with pilotaxic groundmass textures.

\subsubsection{Collinao Dacite}

This comprises a mainly greenish-grey porphyritic dacite with occasional eutaxitic textures $\left(62-69 \% \quad \mathrm{SiO}_{2} ; \quad \mathrm{K}_{2} \mathrm{O}<4 \%\right.$; $5<\mathrm{MgO}+\mathrm{Fe}_{2} \mathrm{O}_{3 \mathrm{t}}<8 \% ; 0.8<\mathrm{ASI}<1.1$ ) (Fig. 3c). The original name of the unit given by Llambías and Rapela (1984) was Collinao dacitic ignimbrite. However, examination in more than 15 localities only revealed one with ignimbritic texture, so we consider it more accurately referred to as a lava rather than an ignimbrite. The phenocryst mineral assemblage is dominated by plagioclase (up $50 \mathrm{vol} \%$ in the coarser grained types), amphibole, biotite, Fe-Ti oxides, quartz and apatite (trace). The groundmass varies from fine-grained micropoikilitic crystalline with the development of snowflake textures and interstitial quartz to felsitic-microgranular in the subvolcanic types. Groundmass minerals are feldspar and quartz with small grains of amphibole, biotite and opaque minerals, titanite and apatite microlites. Amphibole is the dominant ferromagnesian mineral in the quartz-poor dacites. Close to the puesto Collinao (Fig. 1b), the groundmass comprises plagioclase microlites set in the poikilitic groundmass and the only ferromagnesian phase is biotite. Apatite is abundant and appears either as stubby prisms when associated with amphibole or as acicular crystals in the groundmass. The unit is dated at $253 \pm 2 \mathrm{Ma}$ (U-Pb SHRIMP in zircon; Luppo et al., 2019). In the southernmost outcrops of the Collinao Dacite, a subvolcanic facies is exposed comprising a light grey equigranular felsic rock $\left(74-77 \% \mathrm{SiO}_{2} ; \mathrm{K}_{2} \mathrm{O}<5 \% ; 5<\mathrm{MgO}+\mathrm{Fe}_{2} \mathrm{O}_{3 \mathrm{t}}<2 \%\right.$ ), in which tourmaline aggregates are present. Biotite microgranite dikes with localized coarse-grained pods with quartz-tourmaline miaroles are observed intruding the Collinao Dacite. 


\subsubsection{Andesitic dikes}

All the pre-253 Ma magmatic units are crosscut by $<1 \mathrm{~m}$ thick, porphyritic to aphyric, dark grey mafic dikes $\left(49-55 \% \mathrm{SiO}_{2} ; \mathrm{K}_{2} \mathrm{O}<2 \%\right.$; $\left.\mathrm{Fe}_{2} \mathrm{O}_{3 \mathrm{t}}+\mathrm{MgO}<15 \%\right)$ which, in turn, are crosscut by acid microgranite dikes (Luppo et al., 2019). Mafic dikes with a preferred NE-SW trend (Fig. 1b) intrude the Prieto Granodiorite, Donosa Granite and the base of the rhyolite dome. Most are aphyric and composed of euhedral plagioclase in a widely altered fine-grained hornblende and biotite bearing matrix. Other mafic dikes show E-W trends, such as those that intrude the La Esperanza monzogranites and exhibit up to $1 \mathrm{~cm}$ euhedral hornblende crystals embedded in pilotaxic to intersertal matrix (lamprophyres).

\subsubsection{Calvo Granite and acidic dike swarms}

The Calvo Granite is a silica-rich granite (U-Pb SHRIMP zircon age of $250 \pm 2 \mathrm{Ma}$, Pankhurst et al., 2006) associated with aplite and concentric and radial leucogranitic dikes that constitute the last plutonic activity exposed in the area $(246 \pm 2 \mathrm{Ma} ; 244 \pm 2 \mathrm{Ma} \mathrm{U}-\mathrm{Pb}$ SHRIMP zircon ages in Pankhurst et al., 2006; Luppo et al., 2019). The granite crops out as rounded plugs in the surroundings of La Esperanza. It is a medium to coarse grained equigranular pink leucogranite $\left(75-80 \% \mathrm{SiO}_{2} ; 4<\mathrm{K}_{2} \mathrm{O}<5 \% ; \mathrm{MgO}+\mathrm{Fe}_{2} \mathrm{O}_{3 \mathrm{t}}<3 \% ;\right.$ ASI $\left.<1.1\right)$ (Fig. 3d). In the southern N-S trending outcrop, the granite contains occasional K-feldspar megacrysts and/or the amount of biotite increases, sometimes resembling the Donosa granites. It contains quartz, K-feldspar and plagioclase, minor amounts of biotite and magnetite $(<5 \%)$. Garnet has been described to the northeast of Estancia La Esperanza but was not seen by us.

Fine-to very fine-grained granite and banded and/or porphyritic rhyolite dikes intrude all the previous units of this complex (either plutonic or volcanic). In the easternmost sector they are mostly E-W, but in the surrounding of puesto Calvo they radiate following a NE-SW and E-W trend (Fig. 1b). In most cases their length is more than $5 \mathrm{~km}$ long and their width between 1 and $2 \mathrm{~m}$, but porphyritic rhyolite dikes are thicker than the rest and normally form fold hinges in the field (Fig. 1b). The crosscutting relations between dikes of different orientations are not clear since they change trend imitating a ring structure around the subvolcanic Calvo Granite and thus seem to be related to its emplacement.

\section{Geochronology}

We selected three samples to complete the geochronological framework already published in Pankhurst et al. (2006), Martínez Dopico et al. (2017b) and Luppo et al. (2019) (Table 1).

\subsection{U-Pb SHRIMP zircon dating}

A sample of porphyritic biotite granite $10 \mathrm{~km}$ west of Estancia La Esperanza (megacrystic facies of the Giménez Granite) (Z9; 19G $534600 \mathrm{~m}$. E $5525900 \mathrm{~m}$. S) was collected for U-Pb dating on zircons (Fig. 1). Once extracted, zircons were mounted in epoxy together with chips of the Temora standard zircon (Black et al., 2003). Cathodoluminescence (CL) images were used to reveal the internal structures of the polished grains (Fig. 4a). Most zircons were euhedral to subhedral, predominantly translucent and exhibited magmatic zonation (Fig. 4a). Analyses were performed in the SHRIMP RG (Sensitive HighResolution Ion Microprobe) at the Research School of Earth Sciences of the Australian National University in Canberra according to the protocol outlined in Williams (1998). Data were reduced, statistically analysed and plotted with Isoplot 4.1 (Ludwig, 2005). Common Pb corrections were made using ${ }^{207} \mathrm{~Pb}$ (Williams, 1998). Most zircons were largely euhedral to subhedral, predominantly translucent and exhibit magmatic zonation (Fig. 4a). Twenty-two zircons (27 pits in total) were studied in detail, concentrating on rims but testing potential inheritance in some core-rim pairs (grains \#2,14, 17, 18 and 20; Table 2). We only found Middle Devonian inheritance in only one core of zircon grains. The rest of the cores have shown to have ages between 250 and $c a .260$ Ma, produced during the same magmatic event. One result (for \#14.1) was discarded due to high $\mathrm{f}^{206} \mathrm{~Pb}(>5 \%)$. The other zircons frequently exhibited parallel zoning and all had $\mathrm{Th} / \mathrm{U}$ ratios $>0.1$ and were attributed to a magmatic origin as proposed by Maas et al. (1992). In the Tera-Wasserburg diagram, a tight coherent group on Concordia indicates the crystallization age of this facies of the pluton: $21{ }^{238} \mathrm{U} /{ }^{206} \mathrm{~Pb}$ ages gave a weighted mean of $251 \pm 2 \mathrm{Ma}$ ( $95 \%$ confidence level) with a MSWD of 1.4 (Fig. 4b and c). Six zircons ages were ignored because they were either isolated younger (i.e., grain \#6 $242 \mathrm{Ma}$ ) or somewhat older ages (i.e., grains \#3, $20 \approx 260 \mathrm{Ma}$ ), or they had high common lead (i.e., grain \#14).

\section{2. $K$-Ar white mica dating}

Two samples were selected for K-Ar mineral dating from fresh and well exposed areas of acidic and basic dikes from the La Esperanza area. These were Z67b, a coarse-grained variety of the Donosa Granite in Estancia La Esperanza (5443311 mE $55527092 \mathrm{mS}$ ) and D35a, a medium-grained muscovite-bearing leucogranite dike intruding Prieto Granodiorite $4 \mathrm{~km}$ southeast of Puesto Llanquil (554280 m E $5531743 \mathrm{~m} \mathrm{~S}$ ) (Table 3).

The samples were crushed in a steel jaw crusher and sieved to isolate the $300-400 \mu \mathrm{m}$ size fractions. After magnetic separation, muscovite grains from each sample were handpicked under a binocular microscope to obtain homogeneous microcrystalline separates. The purity of the mineral separates is $>99 \%$. Clean micas were ground in pure alcohol to remove the possible altered rims that might have suffered a loss of potassium or argon. The K-Ar methodology used is described in Solé (2009). For potassium analysis X-ray fluorescence with high-dilution fused pearls was used to minimize the matrix effects (Solé and Enrique, 2001). For argon determination a $\mathrm{CO}_{2}$ laser system was used for sample fusion, followed by gas purification (Solé, 2009). Measurements were performed in a MM1200B noble gas mass spectrometer (Instituto de Geologia, UNAM). Age errors are reported at the $2-\sigma$ level (Table 3).

Both samples yielded muscovite-cooling ages of $260 \pm 6 \mathrm{Ma}$, showing rapid cooling of the Donosa Granite, which has a U-Pb zircon crystallization age of $260 \pm 2$ Ma (Martínez Dopico et al., 2017b).

\section{Geochemistry}

We present the first complete comparative WR chemical analysis of major, minor and trace elements for the Prieto Granodiorite, La Esperanza Monzogranite, Donosa Granite, Collinao Dacite, Paileman Rhyolite, Calvo Granite, and two acidic dikes from the area of $\mathrm{La}$ Esperanza (Table 4). The chemical analyses were conducted at ActLabs, Ontario, Canada under their WRA + trace 4Lithoresearch program. Determinations were performed on samples of up to $5 \mathrm{~kg}$ that were screened for alteration in hand specimen and thin sections. Samples were broken using an iron hammer and reduced using an iron-plated jaw crusher and agate mills. X-ray fluorescence spectrometry (XRF) was used for major elements and ICP-MS for trace elements. The precision is better than $1 \%$ for major elements and better than $5 \%$ for trace elements. The collection was complemented with previous major and some minor elementary data of Rapela and Llambías (1985).

Information was processed using GCDKit 5.0 (Janousek et al., 2006) and the scripts of Janousek et al. (2016). In the following text, compositions are expressed recalculated to $100 \%$ anhydrous to minimize the effect of alteration on the samples. However, because samples show scatter in alkali contents, we tested the potential effect of secondary processes using the chemical weathering index of Ohta and Arai (2007) (not shown). The great majority of samples follow the predicted igneous trend, except those of the Las Pampas rhyolite and some of the rhyolite dome of Rapela and Llambías (1985), which follow the linear trends for 


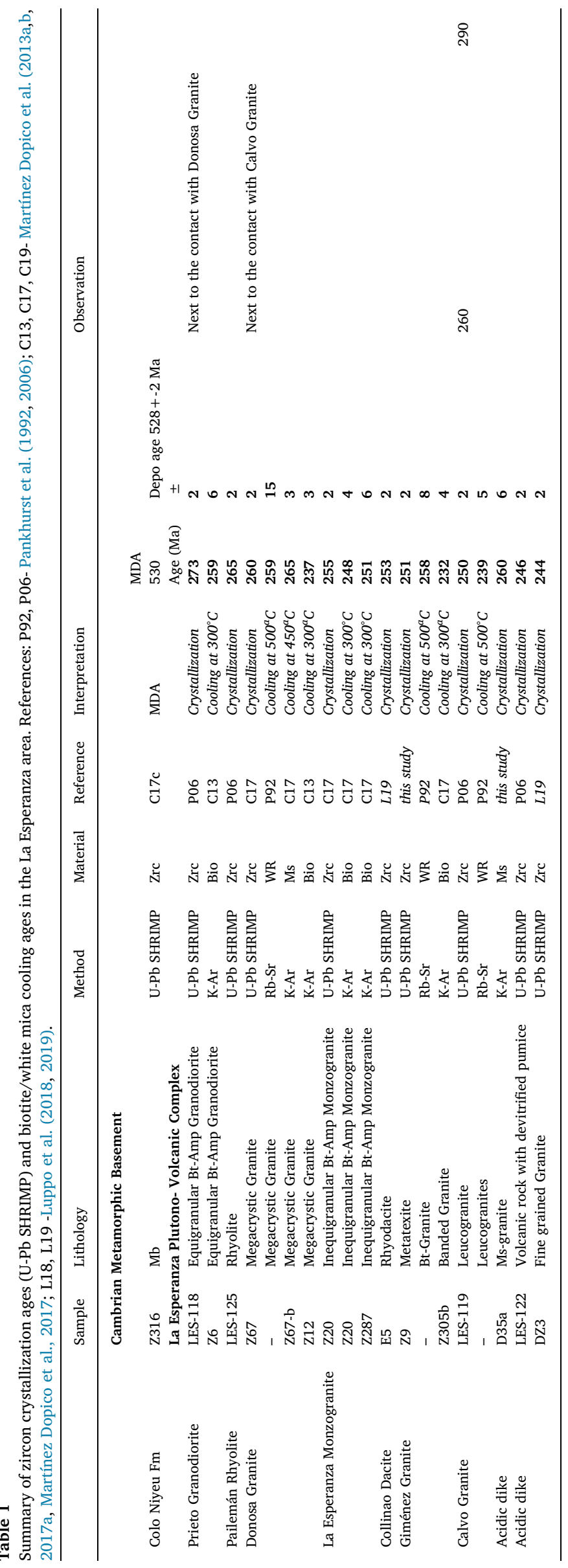




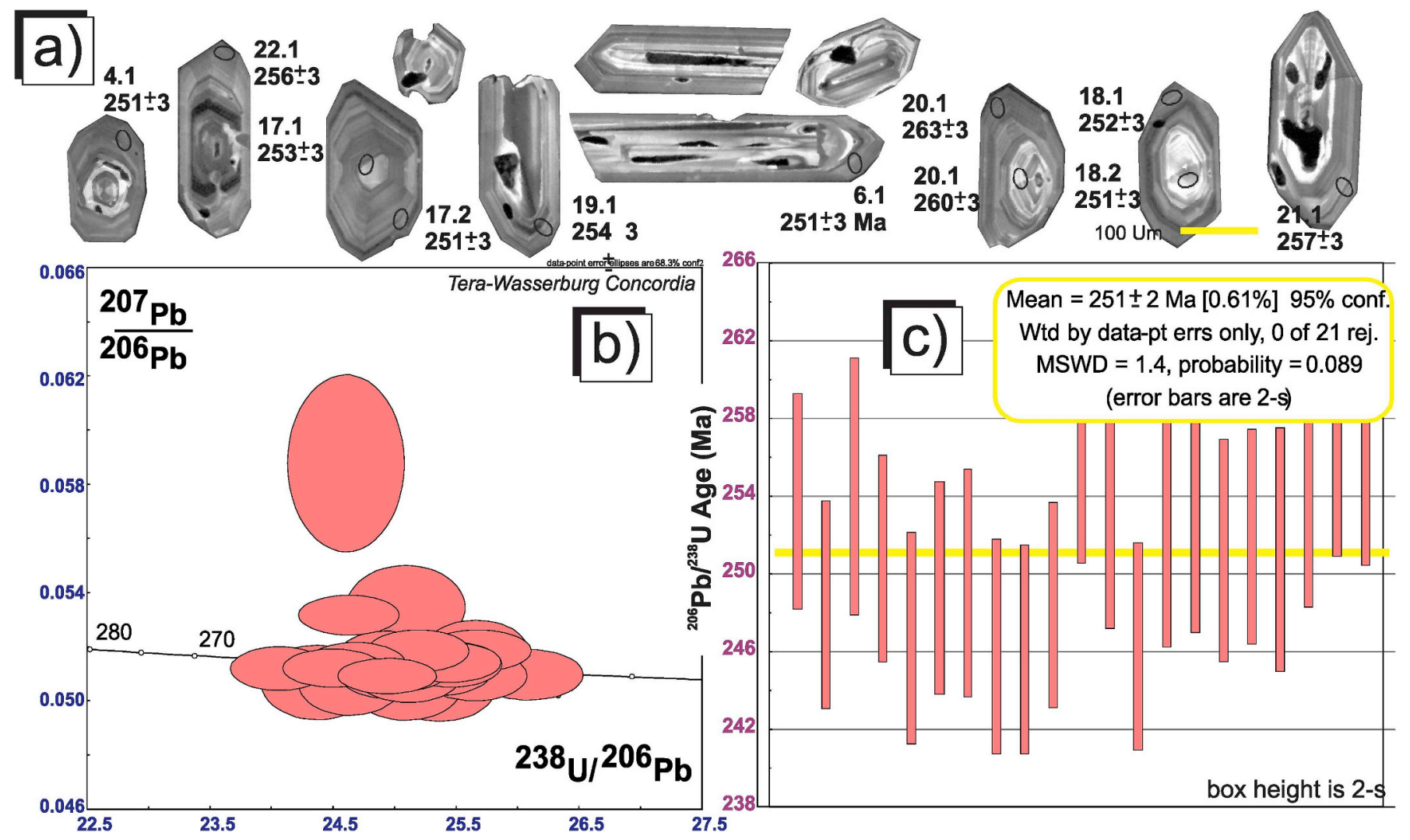

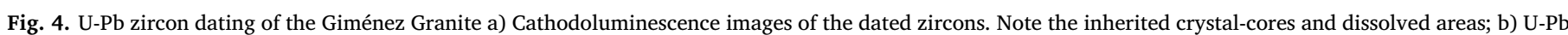
concordia plot; c) Weighted average $\mathrm{U}^{238}-\mathrm{Pb}^{206}$ (SHRIMP) crystallization age for Giménez Granite. A summary of the analytical data is in Table 2.

weathering of rhyolites.

Four unpublished Sr isotopic determinations were taken from the data repository of the Instituto de Geocronología y Geología Isotópica (INGEIS): analytical procedures for these were described in Caminos et al. (1988). Initial ${ }^{87} \mathrm{Sr} /{ }^{86} \mathrm{Sr}$ ratios from the INGEIS data repository, Cingolani et al. (1991) and Pankhurst et al. (1992, 2006) have been recalculated at their respective zircon $\mathrm{U}-\mathrm{Pb}$ crystallization age and using the ${ }^{87} \mathrm{Rb}$ decay constant of Rotenberg et al. (2012) (Table 5). Whole-rock Nd data from Pankhurst et al. (2006) and zircon-Hf isotopic parameters from Fanning et al. (2011) and Castillo et al. (2017) were recalculated using Sm-Nd CHUR of ${ }^{147} \mathrm{Sm} /{ }^{144} \mathrm{Nd}=0.1960 \pm 4$ and ${ }^{143} \mathrm{Nd} /{ }^{144} \mathrm{Nd}=0.512630 \pm 11$, and for Lu-Hf CHUR of ${ }^{176} \mathrm{Lu} /{ }^{177} \mathrm{Hf}=0.0336 \pm 1$ and ${ }^{176} \mathrm{Hf} /{ }^{177} \mathrm{Hf}=0.282785 \pm 11$ of Bouvier et al. (2008).

\subsection{Geochemical variations}

Using the TAS diagram of Middlemost (1994), the Prieto Granodiorite and most of the rocks of the La Esperanza Monzogranite are classified as granodiorites whereas rocks of the base of Collinao Dacite plot as dacites, and andesites. The remaining intrusions and volcanic rocks are compositionally granites or rhyolites.

In the $\mathrm{SiO}_{2}-\mathrm{K}_{2} \mathrm{O}$ diagram of Peccerillo et al. (1976), most units follow a wide high K- calc-alkaline trend (Fig. 5a) and overlap with that of the partial melts derived from tonalites (Roberts and Clemens, 1993). Basic dikes show a transitional character to the medium-K calc-alkaline series (Fig. 5a). In the granite classification of Frost et al. (2001) all the samples belong to the magnesian series. In the modified alkali-lime index diagram (Fig. 5b) the majority of the rocks (Prieto, La Esperanza, Giménez, Donosa and Collinao units) span the calc-alkalic spectrum with most of them between calc-alkalic and calcic fields. On the other hand, the granites of Calvo intrusion and some acidic dikes are alkalicalcic to calc-alkalic. According to Frost et al. (2001), plutons that are genetically related should plot within the same series. In Fig. 5b rocks of Calvo Granite seem to be independent from the rest because at the same $\mathrm{SiO}_{2}$ values, there is a difference in the alkaline-lime ratio. In both bivariate plots is clear that the trends of Prieto Granodiorite, La Esperanza Monzogranite and Collinao Dacite are not subparallel to the proposed lines of chemical differentiation through fractional crystallization within a series (Roberts and Clemens, 1993). Therefore, a significant open-system process such as magma mixing or multiple magma sources may be invoked to explain the variability in the composition of the units. The rocks are mostly metaluminous to slightly peraluminous (ASI $\approx 1.1$ ) and show variable degrees of alumina saturation within the same unit (Fig. 5c). Minor elements important for granites are $\mathrm{Ba}, \mathrm{Sr}$ and $\mathrm{Rb}$ since they replace $\mathrm{Ca}$ and $\mathrm{K}$ in feldspars. Comparing the $\mathrm{Ba}-\mathrm{Sr}$ $\mathrm{Rb}$ compositions of the units (Fig. 5d), two groups can be traced: a group characterized by $\mathrm{Ba} / \mathrm{Sr} \gg 1, \mathrm{Rb} / \mathrm{Ba} \geq 1$ and $\mathrm{Ce} / \mathrm{Sr}>1$ consisting of the Calvo Granite and the fine-grained acidic dikes ("Low Ba-Sr granites"), and another with $\mathrm{Rb} / \mathrm{Ba}<1, \mathrm{Ba} / \mathrm{Sr} \geq 1 \mathrm{Sr} / \mathrm{Rb}>1$ and $\mathrm{Ce}$ / $\mathrm{Sr}<1$ or high Ba-Sr granites (Tarney and Jones, 1994). The high Ba-Sr rocks can be further divided by their $\mathrm{CaO} / \mathrm{K}_{2} \mathrm{O}$ ratio: the Prieto Granodiorite, La Esperanza Monzogranite, Giménez Granite, Collinao Dacite and porphyritic rhyolite dikes have $\mathrm{CaO} / \mathrm{K}_{2} \mathrm{O}>0.5$, in contrast with the Donosa Granite and Pailemán Rhyolite.

Harker diagrams show that $\mathrm{TiO}_{2}, \mathrm{Al}_{2} \mathrm{O}_{3}, \mathrm{CaO}, \mathrm{MgO}, \mathrm{FeO}_{\mathrm{t}}$, and $\mathrm{P}_{2} \mathrm{O}_{5}$ describe inverse relationships relative to $\mathrm{SiO}_{2}$ for the plutonic-volcanic suite, whereas $\mathrm{K}_{2} \mathrm{O}$ and $\mathrm{Na}_{2} \mathrm{O}$ increase or show no correlation with $\mathrm{SiO}_{2}$ (Fig. 6). $\mathrm{Al}_{2} \mathrm{O}_{3}$ shows a decoupled behaviour of the high and low $\mathrm{Sr}-\mathrm{Ba}$ groups with a sudden change in the negative slope, a change replicated in the rest of major element trends, particularly in $\mathrm{Na}_{2} \mathrm{O}$ and $\mathrm{K}_{2} \mathrm{O}$ the trending slope is inverted between the high and low $\mathrm{Sr}$-Ba groups. The different trends seen with alkali-lime index (Fig. 5b) and the sudden change in the slope of the $\mathrm{SiO}_{2}$-major elements trends (Fig. 6) suggests that the low and high Ba-Sr groups are not related to each other by fractional crystallization and might have been sourced from different 


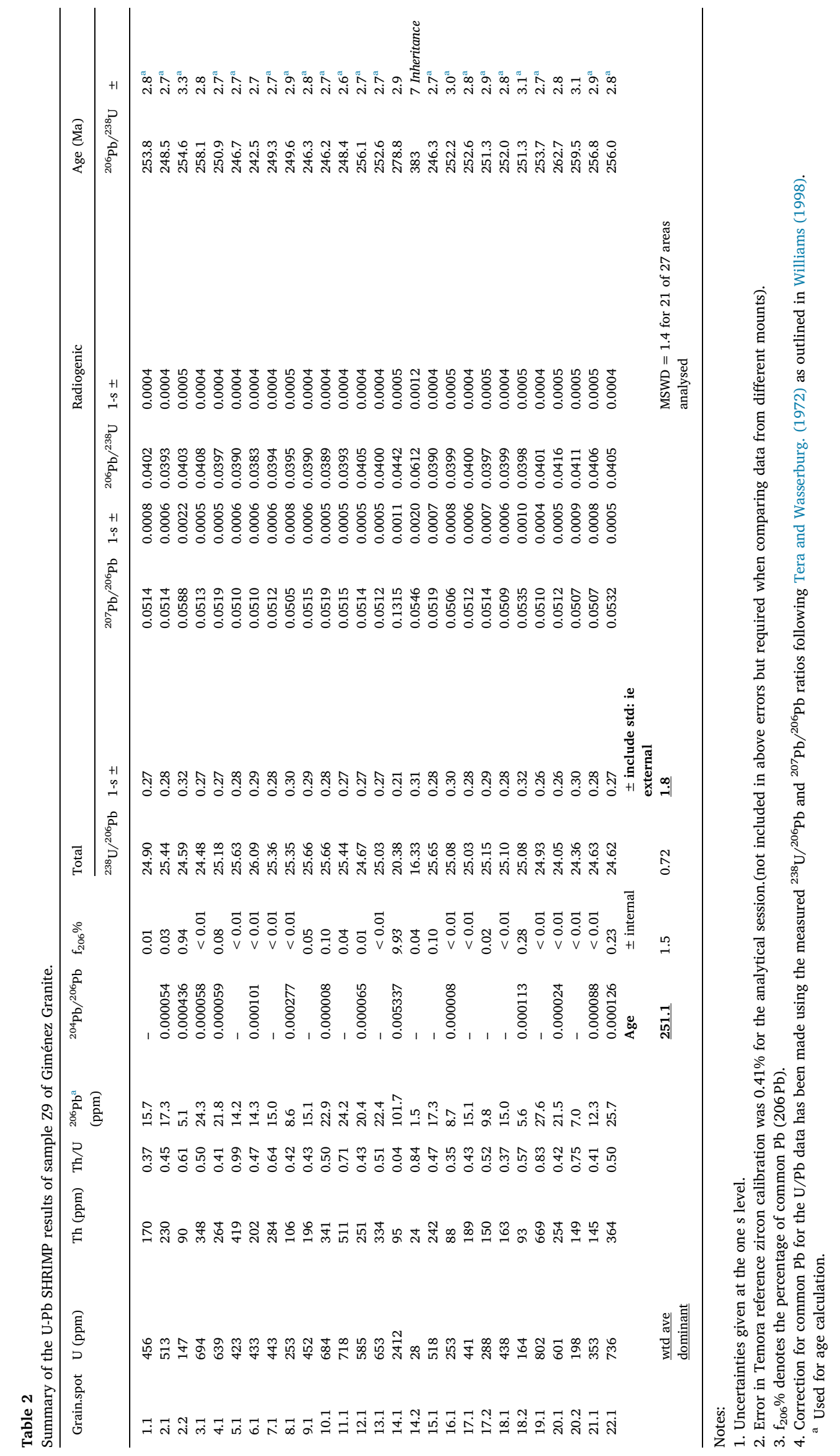


Table 3

Summary of the K-Ar results of muscovite of samples Z67 (Donosa Granite) and D35 (Ms-bearing leucogranite dike).

\begin{tabular}{lllllll}
\hline Sample & Unit & Mineral & $\begin{array}{l}\mathrm{K}_{2} \mathrm{O} \\
{[\mathrm{Wt} . \%]}\end{array}$ & $\begin{array}{l}\text { 40Ar * } \\
{[\%]}\end{array}$ & $\begin{array}{l}\text { Age } \\
{[\mathrm{Ma}]}\end{array}$ & $\begin{array}{l}\text { 2s-Error } \\
{[\mathrm{Ma}]}\end{array}$ \\
\hline Z67b & Donosa Granite & $\mathrm{Ms}$ & 8.41 & 98.3 & 259.6 & 5.8 \\
D35a & Ms-Acid Dike & $\mathrm{Ms}$ & 8.18 & 98.7 & 259.8 & 6.2 \\
\hline
\end{tabular}

protoliths. The variation of $\mathrm{Sr}$ versus $\mathrm{SiO}_{2}$ (Fig. 7) shows a clockwisetrend that also illustrates the behaviour of $\mathrm{Ba}, \mathrm{Zr}, \mathrm{La}$ and Cerium. It is clear from these bivariate diagrams that there are two different segments within each trajectory and a large scatter in the values. In the Prieto Granodiorite, the La Esperanza Monzogranite and the Collinao Dacite they have a crude positive correlation with $\mathrm{SiO}_{2}$, while the granites of Donosa and Calvo and the rhyolite dikes show a vertical scatter. $\mathrm{Rb}$ and $\mathrm{K} / \mathrm{Ba}$ plots vs $\mathrm{SiO}_{2}$ portray anti-clockwise pattern compared to $\mathrm{Sr}$. The variation of $\mathrm{Ba}, \mathrm{K}, \mathrm{Rb}$ within the low-Ba-Sr series (Calvo Granite and fine-grained acidic dikes) suggests K-feldspar fractionation. It is clear from Fig. 7 that there is large scatter of $\mathrm{Sr}$ and $\mathrm{Ba}$ contents in Donosa granites (385-680; 400-1500 ppm, respectively) within a very restricted range of $\mathrm{SiO}_{2}$ values $(73.4-76.0 \%$ weight). The variance of these elements is also large within Giménez granites (265-580; 840-1850 ppm) but within a larger silica range, and with negative correlation between the variables that is not seen in the Donosa Granite. In granites, alkaline earth elements like $\mathrm{Sr}$ and $\mathrm{Ba}$ are usually mostly contained in feldspars replacing $\mathrm{Ca}$ in plagioclase and $\mathrm{K}$ in K-feldspar. In both cases, there are rough positive correlations between $\mathrm{Sr}$ and atomic Ca but not between Ba and atomic K, suggesting fractionation of Ca-plagioclase. In both cases the span of values in trace elements is rather large to be explained solely by this process. According to Clemens et al. (2010) and Villaros et al. (2009) some alkaline-earth elements, such as $\mathrm{Sr}$, in S-type granites are decoupled from the related major elements because their concentrations in the melts are controlled by local variations in the trace-element contents of the source rocks. Moreover, Sr content and its isotopic composition in the different batches of melt would also depend whether equilibrium melting occurs (see Bea, 1996; Farina et al., 2014, among others). As pointed out by Clemens et al. (2009), melts that escape rapidly from the source have less chance to attain equilibrium and may result in lower trace element concentrations compared to those that remain in contact with the source for a long time.

Rare earth element (REE) contents decrease from La to Lu decrease with $\mathrm{SiO}_{2}$, yielding very low values for the Calvo and Donosa granites and the fine-grained rhyolite dikes $(<150 \mathrm{ppm})$. All units are enriched in light rare earth elements (LREE) and display negatively sloping chondrite-normalized REE patterns (Boynton, 1984) (Fig. 8). The La Esperanza Monzogranite, Collinao Dacite and porphyritic rhyolite dikes (Z19) show very similar patterns with $\mathrm{La} / \mathrm{Yb}_{\mathrm{N}}=12.2-17.2$ and weak negative Eu anomalies $\left(\mathrm{Eu} / \mathrm{Eu}^{*}=0.70-0.76\right)$, whereas the older Donosa Granite and the rhyolite dome have more fractionated patterns with $\mathrm{La} / \mathrm{Yb}_{\mathrm{N}}=20.7-27.7$ and weak Eu depletion (Eu/ $\mathrm{Eu}^{*}=0.69-0.76$ ). In contrast, the low Ba-Sr rocks (the Calvo Granite and acidic dikes) show 'wing-shaped' chondrite-normalized REE patterns with large Eu negative anomalies $\left(\mathrm{Eu} / \mathrm{Eu}^{*}=0.36-0.39\right)$.

On multi-element diagrams normalized to primitive-mantle-concentrations, the main rocks of the suite exhibit high contents of LILE such as $\mathrm{Cs}, \mathrm{Rb}, \mathrm{Ba}, \mathrm{Pb}, \mathrm{Th}, \mathrm{U}$ and LREE but negative $\mathrm{Nb}$, Ta and Ti, $\mathrm{P}$ anomalies. Coupled with the overall high-K character, this suggests a strong crustal characteristic of the magmas, with some mafic to intermediate compositions that should have been derived from lower crustal sources (see below isotopic compositions). The low $\mathrm{Ba}-\mathrm{Sr}$ acidic granites and rhyolite dikes (75-80 $\mathrm{SiO}_{2} \mathrm{wt} \%$ ) have a markedly different pattern with larger negative anomalies in $\mathrm{Ba}, \mathrm{Sr}, \mathrm{P}$, and positive anomalies in HREE (Dy, Y, Yb, Lu). Compared to the upper Continental Crust (Taylor and McLennan, 1995), the low Sr-Ba granites and dikes exhibit dramatically lower contents of $\mathrm{Ba}, \mathrm{Sr}, \mathrm{P}$ and $\mathrm{Ti}$ in comparison with the high Ba-Sr rocks. Another thing to note in Fig. 8 is that Donosa granites and the rhyolites of the dome have low values of HREE in comparison to the low $\mathrm{Ba}-\mathrm{Sr}$ rocks at similar $\mathrm{SiO}_{2}$ contents (i.e. $75 \% \mathrm{wt}$ ). This also suggests that the high and low Sr-Rb rocks cannot be derived from a single parental magma.

\subsection{Isotope compositions}

The 'High Ba-Sr' suite shows a narrow range of mean initial ${ }^{87} \mathrm{Sr} /{ }^{86} \mathrm{Sr}$ values from 0.7065 (Prieto Granodiorite) and 0.7071 (La Esperanza Monzogranite) to 0.7076 (Donosa Granite). The initial ${ }^{87} \mathrm{Sr} /{ }^{86} \mathrm{Sr}$ ratios of the volcanic rocks of the rhyolite dome and Collinao Dacite are slightly higher than the plutonic rocks, ranging from 0.7070 to 0.7084 , possibly indicating a more crustal (or hybridized) component than the Prieto Granodiorite (Table 5). Similarly, eNdt values for Calvo Granite and volcanic rocks are largely more negative $(-7.5<\varepsilon N d t<-5.8)$ than those of Prieto Granodiorite $(-4.8)$. Zircon $\varepsilon$ Hft values for the 'High Ba-Sr' rocks $(-2.9$ to -4.6 ; Prieto Granodiorite) are lower than those of Calvo Granite ( -5.6 to -9.0$)$ or rhyolite dikes $(-7.4$ to -8.7$)$. The initial ${ }^{87} \mathrm{Sr} /{ }^{86} \mathrm{Sr}$ ratios of the Calvo Granite at $250 \mathrm{Ma}$ are variable (0.6921-0.7064) ranging to impossibly low values that could indicate post-crystallization open system behaviour. Only initial ${ }^{87} \mathrm{Sr} /{ }^{86} \mathrm{Sr}$ ratio of one sample, LE132, seems more realistic with values of 0.7064 .

Fig. 9 shows the initial ${ }^{87} \mathrm{Sr} /{ }^{86} \mathrm{Sr}$ ratio plotted against $\mathrm{SiO}_{2}$ for the studied rocks. The main rocks of the high Ba-Sr series, the La Esperanza Monzogranite and Giménez Granite, define a horizontal array, suggesting differentiation from a single parent magma, or at least a common source. The initial ${ }^{87} \mathrm{Sr} /{ }^{86} \mathrm{Sr}$ ratios of the Donosa Granite are also coincident with this array, but the age difference between the granites of Giménez (ca. $250 \mathrm{Ma}$ ) and Donosa (260 Ma) precludes a comagmatic relationship, although again a similar source would be possible. Another observation is that the span of initial ${ }^{87} \mathrm{Sr} /{ }^{86} \mathrm{Sr}$ ratios of the rhyolite dome is similar to that of Donosa Granite (at identical wt $\% \mathrm{SiO}_{2}$ ) but unrelated to that of the low $\mathrm{Sr}$-Ba series (considering initial ${ }^{87} \mathrm{Sr} /{ }^{86} \mathrm{Sr}$ values of $\left.c a .0 .7064\right)$. Epsilon Ndt values of Donosa Granite are very negative $(-9.8)$, indicating that the crustal component would be more important than that of the Prieto Granodiorite and the rhyolite dome. However, given the wide spread of $\varepsilon \mathrm{Hft}$ zircon values of the rhyolite dome ( -3.8 to -8.7$)$, more data is necessary to extract a conclusion out of this unit.

\section{Discussion}

\subsection{Temporal and spatial evolution of the magmatic system}

The oldest unit of the area, the Prieto Granodiorite, crystallized at $273 \pm 2 \mathrm{Ma}$ (mid Permian, Cissuralian/Guadalupian) according to a U$\mathrm{Pb}$ SHRIMP zircon dating (Pankhurst et al., 2006) for a sample located less than $1 \mathrm{~km}$ north of the fault contact with the Donosa Granite (Figs. 4 and 10). The crystallization age of the La Esperanza Monzogranite (formerly part of Prieto Granodiorite) is $255 \pm 2 \mathrm{Ma}$ (late Permian, Wuchiapingian/Changhsingian), with biotite cooling ages of $248 \pm 4 \mathrm{Ma}$ and $251 \pm 6 \mathrm{Ma}$ (to the east and west of study area) which reinforce this age (Martínez Dopico et al., 2017b). Initial Sr and $\mathrm{Hf}$ isotope ratios and geochemical features suggest a lower crustal source for both units, consistent with their compositional and textural similarities (Martínez Dopico et al., 2017a). However, the degree of hybridization of the La Esperanza Monzogranite is less than that of the Prieto Granodiorite: it exhibits abundant evidence for mingling whereas the latter is much more homogeneous suggesting less viscosity contrast (i.e. similar temperatures) between interacting melts. On the other hand, emplacement depth differences between them were negligible according to Al-in-hornblende pressure estimates of $<2$ Kbar (Martínez 
Table 4

Typical whole-rock major and trace elements geochemical data of several units of the La Esperanza plutonic-volcanic complex.

\begin{tabular}{|c|c|c|c|c|c|c|c|c|}
\hline Sample & Z19 & DZ3 & LZ13 & D55 & D39 & Z302 & Z67 & $\mathrm{Z} 1$ \\
\hline Locality & $555273 \mathrm{E}$ & $552708 \mathrm{E}$ & $547571 \mathrm{E}$ & $552755 \mathrm{E}$ & $552977 \mathrm{E}$ & $546643 \mathrm{E}$ & $544311 \mathrm{E}$ & $549840 \mathrm{E}$ \\
\hline (UTM m 19G) & $5506688 \mathrm{~S}$ & $5523514 \mathrm{~S}$ & $5535526 \mathrm{~S}$ & $5521004 \mathrm{~S}$ & $5532826 \mathrm{~S}$ & $5525866 \mathrm{~S}$ & $5527092 \mathrm{~S}$ & $5515478 \mathrm{~S}$ \\
\hline Lithology & $\begin{array}{l}\text { porphyritic } \\
\text { rhyolite }\end{array}$ & $\begin{array}{l}\text { aphyric } \\
\text { rhyolite }\end{array}$ & leucogranite & hb- bt granite & rhyolite & dacite & $\begin{array}{l}\text { megacrystic } \\
\text { granite }\end{array}$ & bt-hb granodiorite \\
\hline Unit & acidic dike & acidic dike & Calvo Granite & $\begin{array}{l}\text { La Esperanza } \\
\text { Monzogranite }\end{array}$ & Paileman dome & Collinao Dacite & Donosa Granite & Prieto Granodiorite \\
\hline $\mathrm{SiO}_{2}$ & 69.52 & 78.60 & 75.89 & 69.20 & 74.20 & 60.06 & 74 & 64.08 \\
\hline $\mathrm{Al}_{2} \mathrm{O}_{3}$ & 14.42 & 12.00 & 12.28 & 14.70 & 14.10 & 16.88 & 14.29 & 15.09 \\
\hline $\mathrm{Fe}_{2} \mathrm{O}_{3} \mathrm{t}$ & 3.56 & 2.15 & 0.73 & 3.97 & 1.97 & 6.02 & 1.89 & 5.41 \\
\hline $\mathrm{MnO}$ & 0.06 & 0.02 & 0.08 & 0.07 & 0.03 & 0.05 & 0.029 & 0.075 \\
\hline $\mathrm{MgO}$ & 1.20 & 0.02 & 0.11 & 1.21 & 0.37 & 2.41 & 0.43 & 2.22 \\
\hline $\mathrm{CaO}$ & 2.41 & 0.26 & 0.62 & 2.85 & 1.31 & 4.78 & 1.72 & 3.73 \\
\hline $\mathrm{Na}_{2} \mathrm{O}$ & 3.74 & 3.27 & 3.87 & 3.52 & 3.34 & 3.73 & 3.99 & 3.42 \\
\hline $\mathrm{K}_{2} \mathrm{O}$ & 4.03 & 4.97 & 5.04 & 3.83 & 3.89 & 2.04 & 3.77 & 4.83 \\
\hline $\mathrm{TiO}_{2}$ & 0.42 & 0.09 & 0.10 & 0.42 & 0.18 & 0.84 & 0.23 & 0.57 \\
\hline $\mathrm{P}_{2} \mathrm{O}_{5}$ & 0.13 & 0.01 & 0.01 & 0.13 & 0.03 & 0.23 & 0.09 & 0.15 \\
\hline LOI & 1.10 & 0.12 & 0.46 & 0.58 & 0.89 & 2.16 & 0.7 & 0.86 \\
\hline Total & 100.60 & 101.51 & 99.19 & 100.48 & 100.31 & 99.19 & 101.14 & 100.44 \\
\hline Sc & 7 & 2 & 4 & 7 & 2 & 13 & 3 & 10 \\
\hline $\mathrm{Be}$ & 2 & & 6 & n.d. & n.d. & 3 & 3 & 3 \\
\hline V & 62 & 57 & 9 & 64 & 19 & 137 & 20 & 99 \\
\hline $\mathrm{Cr}$ & 20 & 20 & 20 & 20 & 10 & 20 & 20 & 30 \\
\hline Co & 7 & 1 & 1 & 9 & 2 & 10 & 2 & 11 \\
\hline $\mathrm{Ni}$ & 20 & 7 & 20 & 7 & 5 & 20 & 20 & 20 \\
\hline $\mathrm{Cu}$ & 60 & 15 & 10 & 14 & 4 & 10 & 10 & 10 \\
\hline $\mathrm{Zn}$ & 40 & 9 & 30 & 40 & 31 & 40 & 30 & 60 \\
\hline $\mathrm{Ga}$ & 17 & 13.9 & 19 & 17.5 & 18 & 23 & 20 & 19 \\
\hline $\mathrm{Ge}$ & 1 & 5 & 3 & 5 & 5 & 2 & 1 & 1 \\
\hline As & 5 & 1.9 & 5 & 0.9 & 1.9 & 31 & 5 & 5 \\
\hline $\mathrm{Rb}$ & 140 & 256 & 348 & 171.5 & 158 & 90 & 144 & 225 \\
\hline $\mathrm{Sr}$ & 402 & 49.1 & 35 & 388 & 450 & 593 & 476 & 392 \\
\hline $\mathrm{Y}$ & 14 & 17.9 & 17 & 18.6 & 8.7 & 24 & 6 & 18 \\
\hline $\mathrm{Zr}$ & 146 & 88 & 80 & 136 & 109 & 204 & 112 & 173 \\
\hline $\mathrm{Nb}$ & 12 & 18.5 & 29 & 15.8 & 9.4 & 14 & 9 & 11 \\
\hline Mo & 2 & 2 & 2 & 1 & 1 & 2 & 2 & 2 \\
\hline $\mathrm{Ag}$ & 0.5 & 0.5 & 0.5 & 0.5 & 0.5 & 1.1 & 0.5 & 0.5 \\
\hline In & 0.2 & 0.006 & 0.2 & 0.014 & 0.005 & 0.2 & 0.2 & 0.2 \\
\hline Sn & 3 & 3 & 4 & 3 & 2 & 5 & 2 & 4 \\
\hline $\mathrm{Sb}$ & 0.5 & 0.2 & 0.5 & 0.14 & 0.71 & 1.3 & 0.5 & 0.5 \\
\hline Cs & 2.2 & 1.71 & 6.9 & 8.33 & 9.12 & 4.5 & 3.1 & 9.1 \\
\hline $\mathrm{Ba}$ & 1102 & 102.5 & 110 & 808 & 1110 & 542 & 913 & 800 \\
\hline $\mathrm{La}$ & 38.4 & 32 & 22.4 & 42 & 24.6 & 41.9 & 24.4 & 50.3 \\
\hline $\mathrm{Ce}$ & 73.6 & 59.2 & 42.3 & 77.5 & 46.1 & 87 & 47.4 & 99.1 \\
\hline $\operatorname{Pr}$ & 7.47 & 5.42 & 3.87 & 8.17 & 4.91 & 9.76 & 4.95 & 10.1 \\
\hline $\mathrm{Nd}$ & 26.1 & 15.8 & 11.4 & 27.7 & 17.7 & 36.7 & 17.2 & 34.8 \\
\hline $\mathrm{Sm}$ & 4.5 & 2.58 & 1.9 & 4.66 & 2.66 & 6.8 & 3 & 6 \\
\hline $\mathrm{Eu}$ & 0.93 & 0.29 & 0.2 & 0.95 & 0.49 & 1.35 & 0.58 & 1.13 \\
\hline $\mathrm{Gd}$ & 3.1 & 2.05 & 1.5 & 3.34 & 1.79 & 5 & 1.8 & 4.2 \\
\hline $\mathrm{Tb}$ & 0.5 & 0.4 & 0.3 & 0.54 & 0.29 & 0.8 & 0.3 & 0.6 \\
\hline Dy & 2.7 & 2.24 & 1.9 & 3.02 & 1.48 & 4.3 & 1.3 & 3.3 \\
\hline Ho & 0.5 & 0.56 & 0.4 & 0.61 & 0.29 & 0.8 & 0.2 & 0.6 \\
\hline $\mathrm{Er}$ & 1.5 & 1.69 & 1.5 & 1.71 & 0.76 & 2.3 & 0.7 & 1.8 \\
\hline $\mathrm{Tm}$ & 0.22 & 0.28 & 0.31 & 0.26 & 0.12 & 0.34 & 0.1 & 0.28 \\
\hline $\mathrm{Yb}$ & 1.5 & 2.13 & 2.6 & 1.71 & 0.8 & 2.3 & 0.6 & 1.9 \\
\hline $\mathrm{Lu}$ & 0.25 & 0.32 & 0.48 & 0.25 & 0.12 & 0.36 & 0.1 & 0.3 \\
\hline $\mathrm{Hf}$ & 4.5 & 3.6 & 4 & 3.9 & 3.2 & 5.4 & 3.3 & 5.5 \\
\hline $\mathrm{Ta}$ & 1.3 & 1.5 & 2.9 & 1.6 & 0.9 & 1.3 & 1.1 & 1.2 \\
\hline $\mathrm{W}$ & 2 & 2 & 1 & 3 & 7 & 1 & 1 & 5 \\
\hline $\mathrm{Tl}$ & 0.9 & 0.08 & 1.7 & 0.3 & 0.13 & 0.5 & 0.6 & 1.2 \\
\hline $\mathrm{Pb}$ & 18 & 16 & 37 & 21 & 14 & 14 & 22 & 29 \\
\hline $\mathrm{Bi}$ & 0.4 & 0.17 & 0.4 & 0.19 & 0.06 & 0.5 & 0.4 & 0.6 \\
\hline Th & 14.6 & 25.6 & 33.3 & 19.1 & 9.11 & 23.6 & 8 & 28.5 \\
\hline $\mathrm{U}$ & 4.6 & 2.28 & 5.5 & 3.28 & 2.11 & 5.8 & 1.9 & 7.6 \\
\hline $\mathrm{Eu} / \mathrm{Eu}^{*}$ & 0.76 & 0.39 & 0.36 & 0.74 & 0.69 & 0.71 & 0.76 & 0.69 \\
\hline $\mathrm{La} / \mathrm{YbN}$ & 17.26 & 10.13 & 5.81 & 16.56 & 20.73 & 12.28 & 27.42 & 17.85 \\
\hline $\mathrm{La} / \mathrm{SmN}$ & 5.37 & 7.8 & 7.42 & 5.67 & 5.82 & 3.88 & 5.12 & 5.27 \\
\hline Sum REE & 161.27 & 124.96 & 91.06 & 172.42 & 102.11 & 199.71 & 102.63 & 214.41 \\
\hline
\end{tabular}

Dopico et al., 2013a). The Prieto Granodiorite is exposed as the host of the rhyolite dome whose basal unit (i.e. crystaloclastic rhyolite) was dated at $264 \pm 2 \mathrm{Ma}$. However, the rhyolite dome is a complex subvolcanic/volcanic edifice whose age range has not yet been accurately constrained and could extend to Lower Triassic times. Crystallization and cooling of the Donosa Granite in the central part of the main body have been dated as $260 \pm 2 \mathrm{Ma}$ (late Permian, Wuchiapingian/Capitanian, U-Pb on zircon age) with a very fast cooling from 400 to $350{ }^{\circ} \mathrm{C}$ to at $259 \pm 6 \mathrm{Ma}$ (K-Ar on muscovite age presented here, Table 3, Fig. 10). Textural evidence of near-surface cooling is seen in the $1-2 \mathrm{~cm}$ 


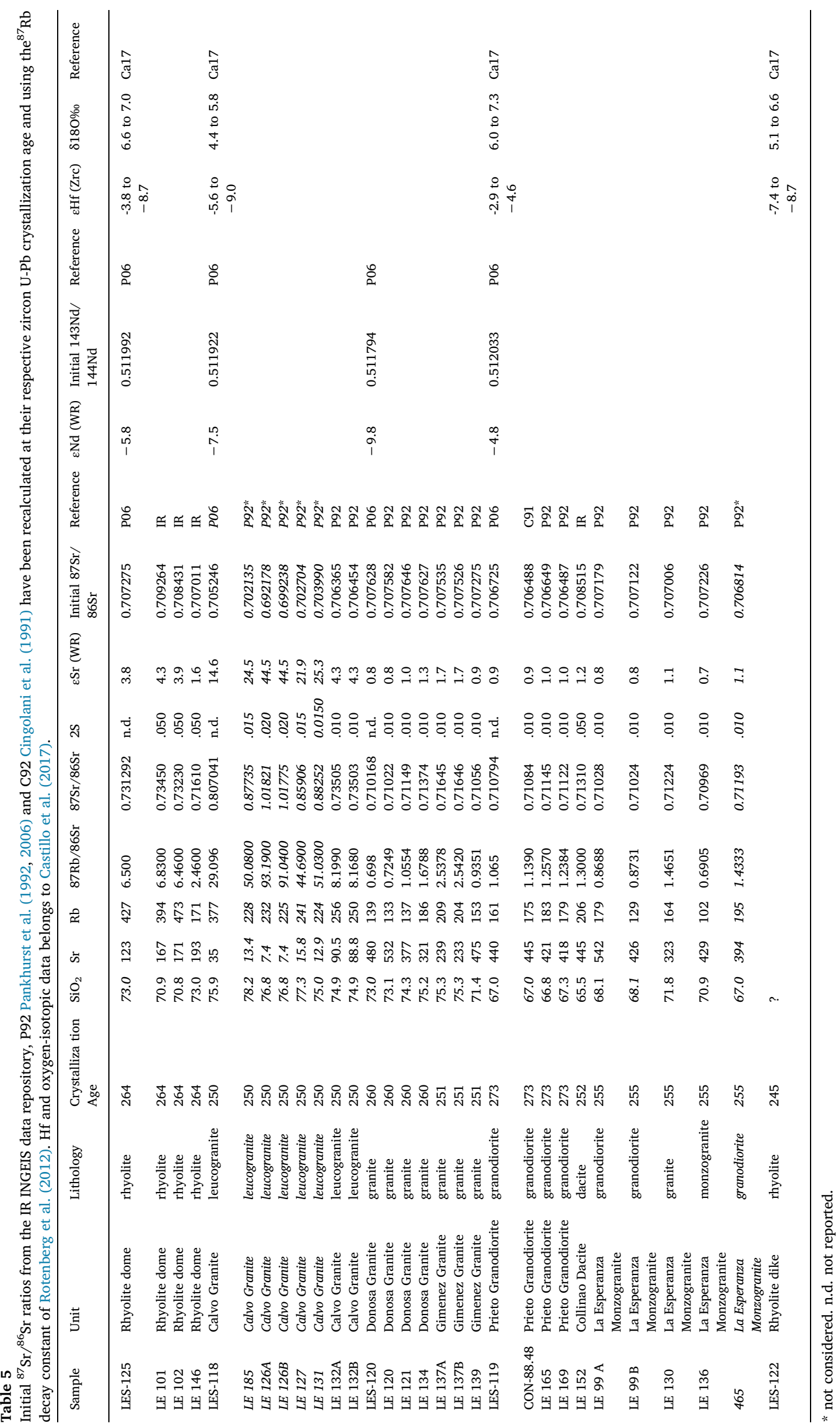



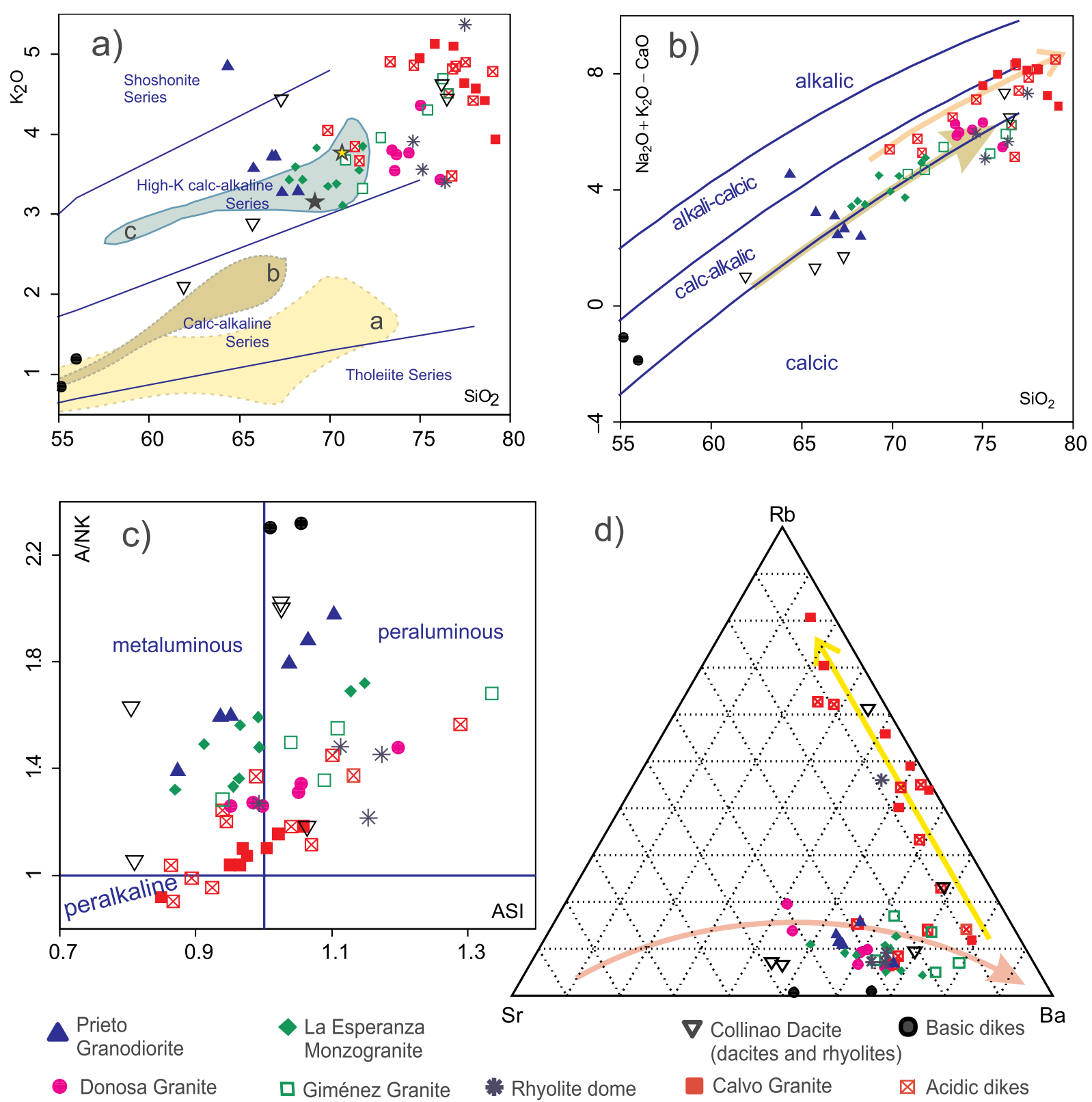

Fig. 5. Major element geochemistry of the La Esperanza plutonic-volcanic complex (this paper; Rapela and Llambías, 1985). a) Binary diagram of $\left(\mathrm{K}_{2} \mathrm{O}+\mathrm{Na}_{2} \mathrm{O}\right)$ vs $\mathrm{SiO}_{2}$ (Middlemost, 1994) shows that most units follow a wide high K- calc-alkaline trend. The black and white stars represent average I- and S-type granite compositions reported by Chappell and White (1983) whereas fields a, b and c show the trends of differentiation of three examples of plutonic magma series: transitional, calc-alkaline and high-K rocks, respectively shown as in Roberts and Clemens (1993); b) Binary modified-alkali-lime index (Frost et al., 2001) vs $\mathrm{SiO}_{2}$; note that the Prieto, La Esperanza, Giménez, Donosa and Collinao units extend over the calc-alkalic and calcic fields whereas Calvo Granite and some acidic dikes belong to the alkali-calcic to calc-alkalic domains; c) Alumina saturation indexes $\mathrm{Al}_{2} \mathrm{O}_{3} /\left[\left(\mathrm{CaO}+\mathrm{Na}_{2} \mathrm{O}+\mathrm{K}_{2} \mathrm{O}\right)-\left(1.67 * \mathrm{CaO}^{2}\right)\right] \mathrm{vs}$. $\mathrm{Al}_{2} \mathrm{O}_{3} /\left(\mathrm{Na}_{2} \mathrm{O}+\mathrm{K}_{2} \mathrm{O}\right)(\mathrm{mol}$. \%); and d) Sr-Rb-Ba Ternary diagram showing high and low Ba-Sr groups.

euhedral crystals of quartz in localities around Arroyo del Corral (Fig. 1b), which indicate very fast cooling of the unit and its very shallow character. Muscovite-bearing microgranite dikes (Table 3; sample D35b) could be associated either with the Pailemán Rhyolite or with the Donosa Granite (both rocks contain primary muscovite), and they intrude the Prieto Granodiorite.

Slightly after intrusion of the La Esperanza Monzogranite, the Collinao Dacite was extruded at $253 \pm 2$ Ma (Luppo et al., 2019) along a N-S trending ridge. The Collinao Dacite clearly overlies the main body of Donosa granites, but contact with the La Esperanza Monzogranite occurs where the granite is highly fractured and altered (Fig. 1b). The following event is the intrusion of Calvo Granite, dated at $250 \pm 2 \mathrm{Ma}$ by Pankhurst et al. (2006). Although there are no available geochronological constraints on the mafic NW-SE dyke swarm, these dikes intrude the La Esperanza Monzogranite and the Giménez Granite. Therefore, these dikes are constrained as close in time to the extrusion of Collinao Dacite, after the intrusion of Giménez Granite at $251 \pm 2 \mathrm{Ma}$ (Fig. 1b), but before the $\approx 244 \mathrm{Ma}$ acid dikes (Luppo et al., 2019 ). The $\approx 244$ Ma acidic dikes clearly crosscut all the units of the LEPVC, following E-W, NE-SW and NW-SE trends and are geochemically related to the Calvo Granite (250 \pm 2 Ma, Pankhurst et al., 2006).

\subsection{The unconformity between the La Esperanza plutonic and volcanic} rocks

In the first approach to the geology of the La Esperanza magmatic 

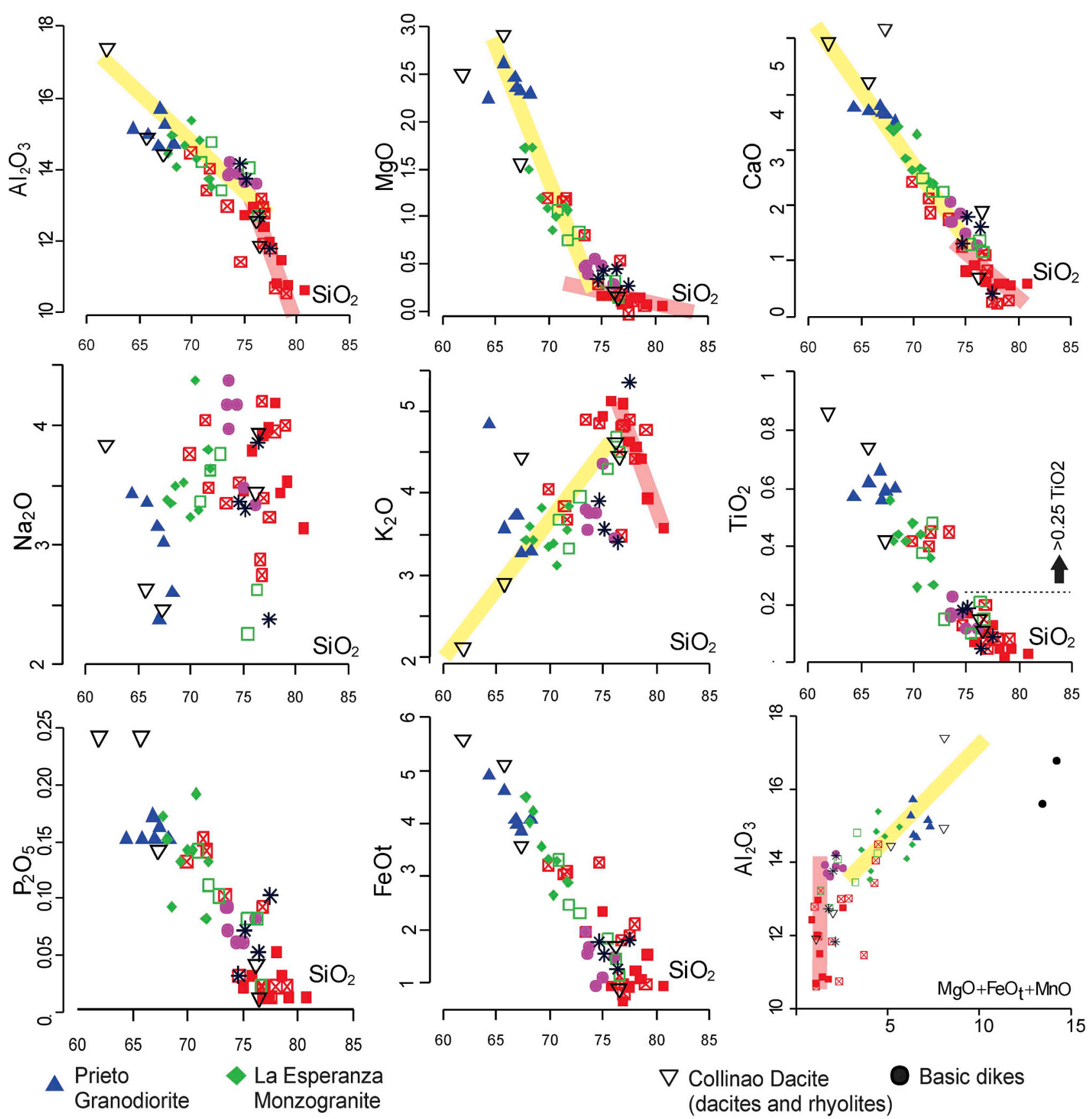

Donosa Granite $\square$ Giménez Granite

* Rhyolite dome

$\nabla$ Collinao Dacite
(dacites and rhy

Basic dikes (dacites and rhyolites)

Fig. 6. Major element (wt\%) variation diagrams versus $\mathrm{SiO}_{2}$ for entire chemical data set of the granitoid and volcanic groups. Yellow and pink lines indicate suggested evolutionary trends of low and high Sr-Ba groups, respectively. (For interpretation of the references to color in this figure legend, the reader is referred to the Web version of this article.)

system, Llambías and Rapela (1984) and Rapela and Llambías (1985) divided the rocks around Estancia La Esperanza in two cycles, the first entirely plutonic and the second volcanic and subvolcanic including the Calvo Granite and acidic dikes. Llambías and Rapela (1984) claim "The second Cycle begins after a short erosive period that uncovers the plutonic rocks of the first Cycle and on which in almost horizontal surfaces the first ignimbritic eruptions of dacitic composition (Collinao) were deposited." In the light of the new stratigraphic arrangement (Fig. 10), this simple subdivision does not hold anymore. There is an erosion surface between the Donosa Granite and the Collinao Dacite which is easily seen around Estancia La Esperanza. A second erosion surface might occur between the Permian rocks and the Calvo Granite and associated dikes ( $<250 \mathrm{Ma}$ ). In any case, in the La Esperanza area none of these erosion surfaces seem to represent more than minor adjustments associated with the evolution of the caldera rather than substantial discordances. Further south, rhyolitic ignimbrites, dacite lavas and rhyolitic tuffs at the base and middle sections of the coeval Los Menucos Group (252-258 Ma) were tilted ( $30^{\circ}$ to the east) and intruded by a felsic rhyolite dike swarm equivalent to the group of acidic dikes in La Esperanza. The acidic dikes of the La Esperanza area (Fig. 1) were dated as old as $244 \pm 2 \mathrm{Ma}$ (crystallization age of a finegrained rhyolite dike; Luppo et al., 2019), suggesting that regional uplift and erosion occurred between the emplacement of Calvo Granite ( $250 \pm 2$ Ma crystallization age of the northern plug of the Calvo 

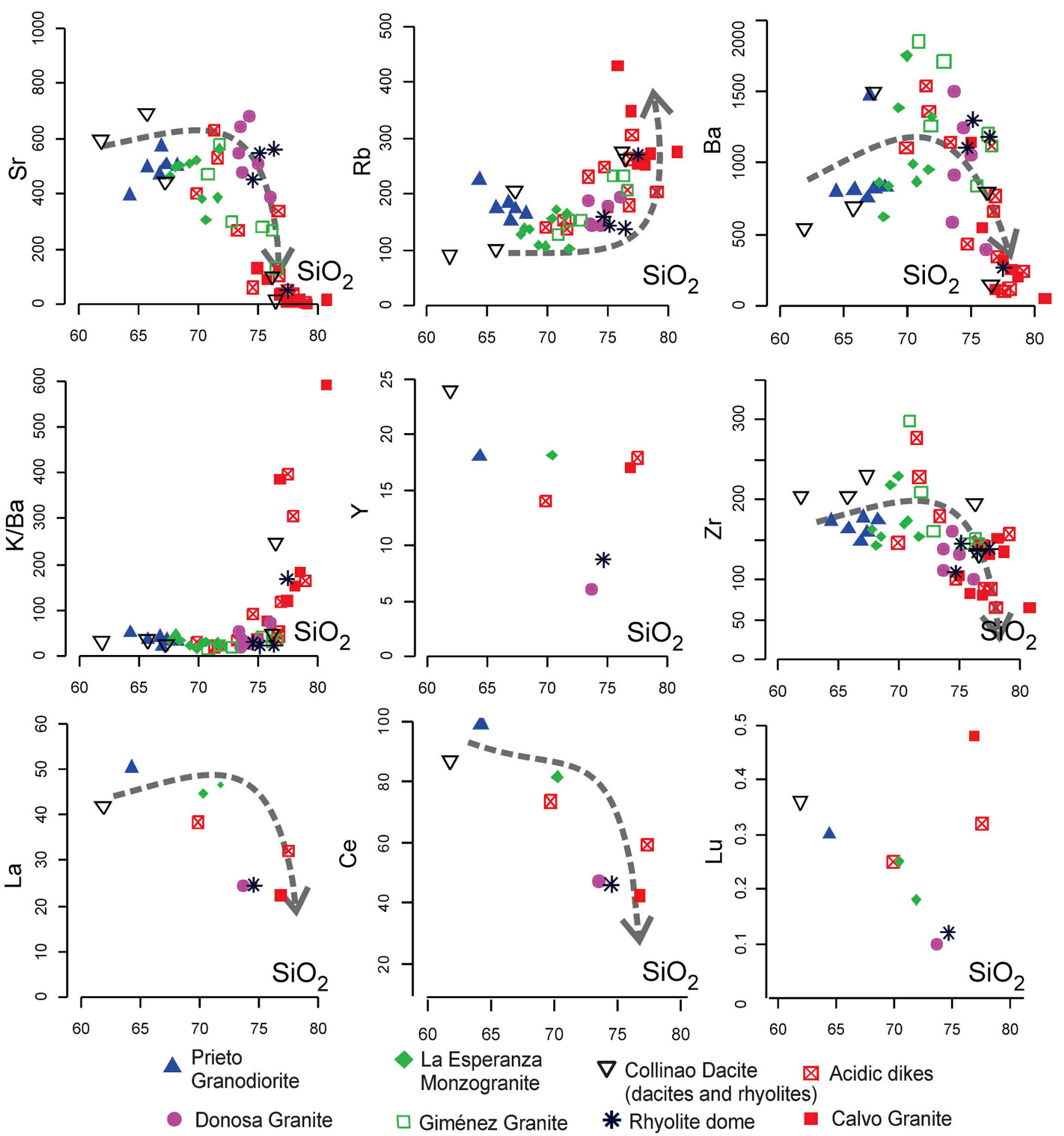

Fig. 7. Selected trace elements ( $\mathrm{Sr}, \mathrm{Rb}, \mathrm{Ba}, \mathrm{Y}, \mathrm{Zr}, \mathrm{La}, \mathrm{Ce}, \mathrm{Lu}$; ppm) versus $\mathrm{SiO}_{2}$ variation diagrams for the entire chemical data set of the granitoid and volcanic groups.

Granite; Pankhurst et al., 2006) and the diking.

\subsection{Petrogenesis and magmatic kinships}

The early Permian Prieto Granodiorite $(273 \pm 2 \mathrm{Ma})$ shares major and trace element geochemical characteristics with the late Permian monzogranites and granites of the La Esperanza Monzogranite $(255 \pm 2 \mathrm{Ma})$ and its extrusive counterpart, the Collinao Dacite $(253 \pm 2 \mathrm{Ma})$. All these rocks contain early crystallizing phases such as orthopyroxene, magnesian clinoamphibole and plagioclase, followed by late hornblende and biotite, titanite and allanite, but lack peraluminous minerals, suggesting that their parental magmas were hydrated and metaluminous. According to the amphibole chemistry of the granodiorites and monzogranites (data in Martínez Dopico et al., 2013a,b) and following the equations of Ridolfi et al. (2010) and Ridolfi and Renzulli (2012), crystallization occurred in similar oxidizing $\left(\mathrm{fO}_{2}\right.$ $\approx \mathrm{NNO}$ ) and hydrous conditions ( $4>\mathrm{H}_{2} \mathrm{O}>5 \% \mathrm{wt}$ ). Minimum crystallization temperatures estimated using the zircon saturation thermometer (TZr, Watson and Harrison, 1983) yielded temperatures of $c a$. $760{ }^{\circ} \mathrm{C}$ for Prieto and La Esperanza granodiorites and $\mathrm{ca} .800{ }^{\circ} \mathrm{C}$ for the 

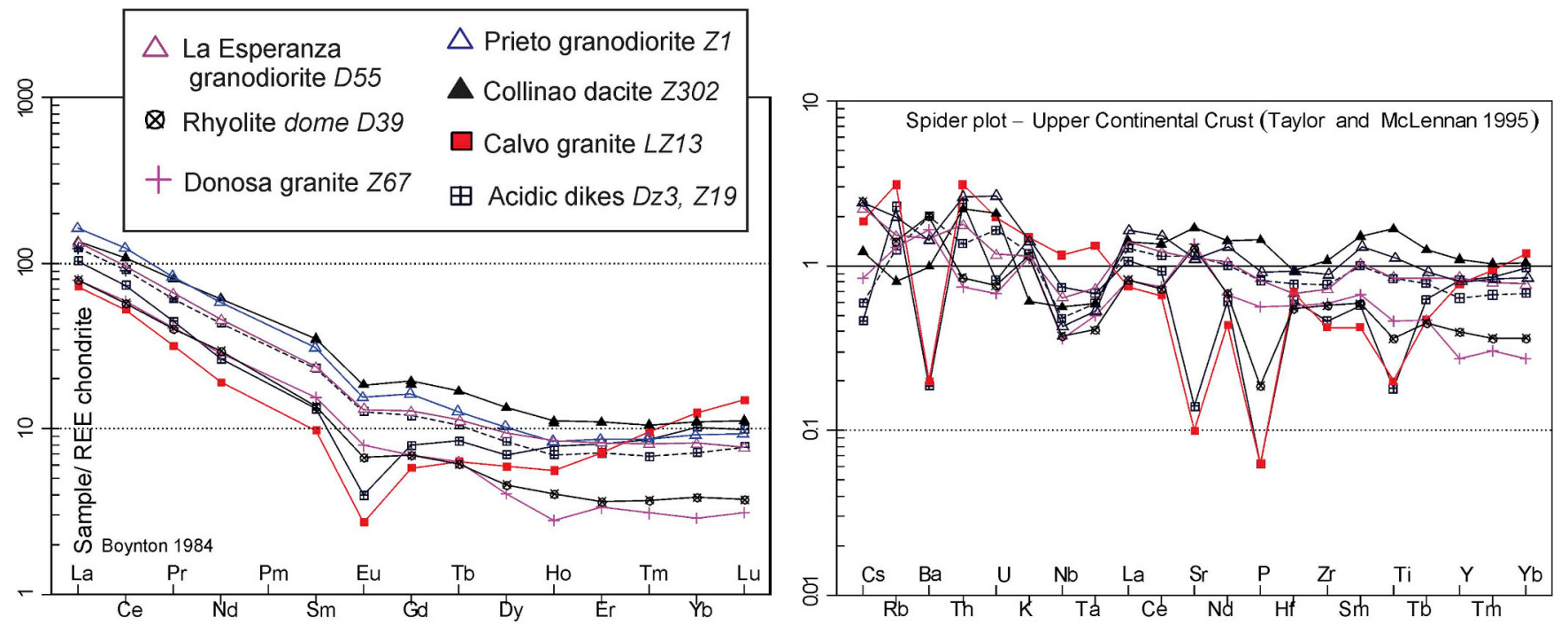

Fig. 8. Chondrite-normalized REE patterns normalized to values of Boynton (1984) (left) and Spider plot of values normalized to the Upper Continental Crust of Taylor and McLennan (1995) (right).

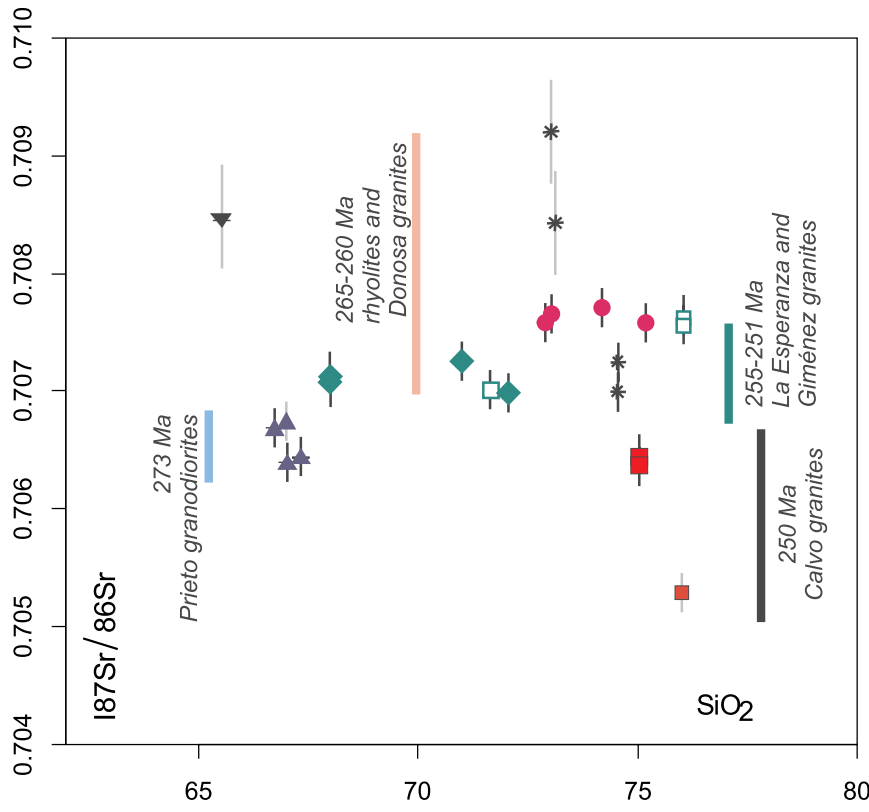

Fig. 9. Initial ${ }^{87} \mathrm{Sr} /{ }^{86} \mathrm{Sr}$ ratio vs $\mathrm{SiO}_{2}$ of the units of the La Esperanza plutonicvolcanic complex. Data from the INGEIS data repository, Pankhurst et al. (1992, 2006), and Cingolani et al. (1991) were recalculated at the crystallization ages using the ${ }^{87} \mathrm{Rb}$ decay constant of Rotenberg et al. (2012). Data table as supplementary material and symbols as in Fig. 7.

later porphyritic granite facies of La Esperanza Monzogranite and Collinao dacites, indicating that magma temperature increased with time. The lack of inherited zircon ages (see Martínez Dopico et al., 2017a; Luppo et al., 2019 and Table 2) and the absence of correlation between $\mathrm{Zr}$ and $\mathrm{SiO}_{2}$ suggest that these are minimum temperatures for the magmas.

Initial ${ }^{87} \mathrm{Sr} /{ }^{86} \mathrm{Sr}$ ratios, mineralogy as well as crystallization ages suggest that the Giménez Granite is an evolved magma batch ( $>70 \%$ $\mathrm{SiO}_{2}$ ) derived from the fractionation of La Esperanza Monzogranite magmas. Major element trends show that it was formed after extensive amphibole and Ca-plagioclase fractionation. All rocks with $<70 \% \mathrm{SiO}_{2}$ show coherent $\mathrm{Sm} / \mathrm{Yb}$ ratios from 3.0 to 4.5 , indicating that pyroxene and mainly amphibole were present in the source. This would suggest that the first batch of melt had left hornblende and pyroxene as major residual phases at high $\mathrm{T}$ and low $\mathrm{P}$ melting conditions of a mafic metaigneous source. Whole-rock initial ${ }^{87} \mathrm{Sr} /{ }^{86} \mathrm{Sr}$ (0.7064-0.7067; Table 5), Nd ( $\varepsilon \mathrm{Nd}=-4.8$ )-and zircon $\mathrm{Hf}$ isotope compositions ( $\varepsilon \mathrm{Hf}$ of -2.9 to -4.6 ; Castillo et al., 2017) for the intermediate rocks of the Prieto Granodiorite are compatible with the interpretation that these magmas were extracted from a mafic or intermediate source with longterm crustal residence. Even though there is a 20 Ma gap between the pulses, the La Esperanza Monzogranite and Giménez Granite seem to share a common ancestry with the Prieto Granodiorite at the same crustal level. However, the higher initial ${ }^{87} \mathrm{Sr} /{ }^{86} \mathrm{Sr}$ of the more evolved members of the La Esperanza Monzogranite (porphyritic facies; 0.7070-0.7072) and Giménez Granite (0.7072-0.7075; Table 5) suggest that the felsic component increased with time. The higher abundance of mafic microgranular enclaves in the monzogranites and granites of La Esperanza in comparison with the older rocks indicates that magma hybridization was inefficient. Low zircon $\delta^{18} \mathrm{O}$ values for the whole series of rocks of La Esperanza (4.4\%o-7.3\%o; Castillo et al., 2017) confirm an I-type origin (Valley, 2003). Trace element-based granite tectonic discrimination diagrams (Pearce et al., 1984; Pearce, 1996; Harris et al., 1986) also point to I-type volcanic arc sources (syn to postcollisional fields) (not shown; see Martínez Dopico et al., 2014).

Granodiorite/dacite, monzogranite and granite of the La Esperanza area yield a wide range of major and trace element concentrations, suggesting variable degrees of partial melting and probably a rapid escape of the magma that prevented further chemical equilibration with the source. The rough negative correlation between $\mathrm{SiO}_{2}$ and $\mathrm{FeO}_{\mathrm{t}}$, $\mathrm{MgO}, \mathrm{MnO}$ and $\mathrm{TiO}_{2}$, and $\mathrm{La} / \mathrm{Yb}_{\mathrm{N}}, \mathrm{Sr}, \mathrm{Ba}, \mathrm{K}, \mathrm{Y}$ and $\mathrm{Zr}$ indicates that the fractionation of amphibole and plagioclase might have operated for the crystallization of the Prieto Granodiorite, La Esperanza Monzogranite and Collinao Dacite intermediate magmas, as well as the Giménez Granite. In turn, biotite does not seem to have had an important role since $\mathrm{Rb}$ and $\mathrm{Ba}$ (both compatible elements in biotite but not in amphibole) do not decrease with $\mathrm{SiO}_{2}$ or $\mathrm{K}_{2} \mathrm{O}$ (Fig. 7). The decrease in the $\mathrm{Ba}$ content within Donosa would be related to the grain size of the Kfeldspar crystals, and, perhaps, related to K-feldspar fractionation. Minor phases that might have controlled the REE fractionation are allanite or monazite. In turn, the middle-Permian Donosa Granite, Msbearing leucogranites and the rhyolites of the dome are high-SiO $\mathrm{S}_{2}$-type magmas that contain plagioclase as an early crystallizing phase. The growth of muscovite, acid plagioclase and subhedral quartz as well as a disharmonic growth of K-feldspar megacrysts occurred during low-nucleation high-growth rate episode at high-temperature conditions. Hf 


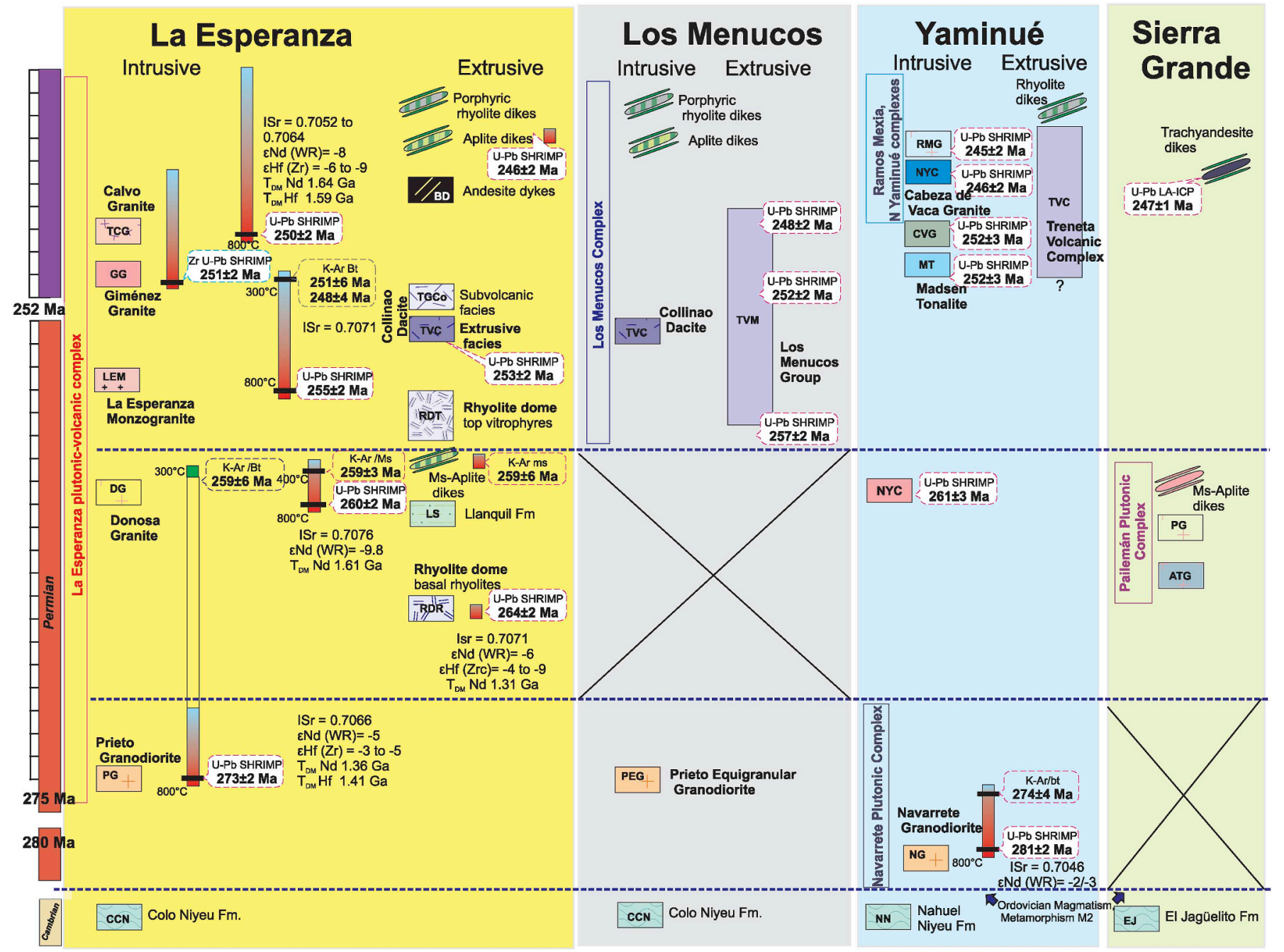

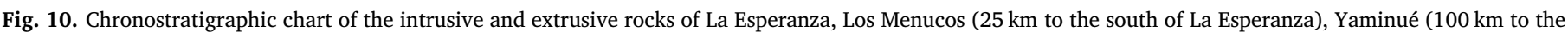

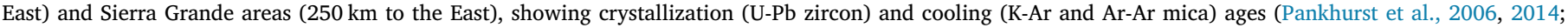

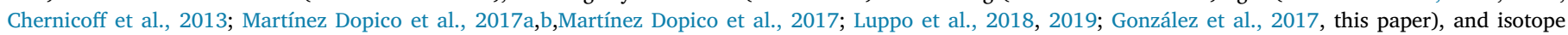
parameters (Pankhurst et al., 2006; Castillo et al., 2017). Note the similarity of the crystallization-time intervals of the plutonic rocks.

data in zircons of the rhyolite dome aged between 260 and $269 \mathrm{Ma}$ show a large variability $(-4<\varepsilon$ Hf- $<11$; Castillo et al., 2017, Table 5), suggesting either a mixing of sources (mid crustal vs lower crustal) or isotopic disequilibrium melting. Three arguments would preclude a potential derivation of the felsic magmas of the granites of Donosa and rhyolites of the dome from the same source as the Prieto Granodiorite. First, the large REE decoupling between the felsic Donosa Granite (average $73 \mathrm{wt} \% \mathrm{SiO}_{2}$ ) and the rocks of the rhyolite dome $\left(74 \mathrm{wt} \% \mathrm{SiO}_{2}\right)$ and the intermediate rocks of the La Esperanza Monzogranite and Giménez Granite (72-75 wt $\left.\% \mathrm{SiO}_{2}\right)$. Second, the different whole-rock trace element compositions (high $v s$ low Ba-Sr) with similar initial $\mathrm{Sr}$ ratios (Table 5). And third, the Nd isotope difference between Prieto Granodiorite $(\varepsilon \mathrm{Nd}=-4.8)$ and Donosa Granite $(\varepsilon \mathrm{Nd}=-9.8)$. Thus, the Prieto Granodiorite and the La Esperanza Monzogranite could have a mixed crustal - mafic source whereas the Donosa Granite and the Pailemán Rhyolite have a stronger crustal signature. On the other hand, there is no overlap in $\mathrm{Sr}, \mathrm{Nd}$ and scant overlap in Hf isotopic composition between the $<250 \mathrm{Ma}$ units, the Calvo Granite and rhyolite dikes, and any other group of rocks. The non-disturbed initial ${ }^{87} \mathrm{Sr} /{ }^{86} \mathrm{Sr}$ ratios for the early Triassic rocks $(<250 \mathrm{Ma})$ are low $\left(0.7052-0.7064\right.$ at $\left.75 \% \mathrm{SiO}_{2}\right)$, coupled with mantle-like $\mathrm{O}^{18}$ values (4.4-6.6\%) for zircon with $-5.6<\varepsilon \mathrm{Hf}<-9.0$ units giving the rocks a distinctive signature compared to the older rocks.
6.4. Inferences for the tectonic setting and connections with other plutonic or plutonic-volcanic complexes in Patagonia and surroundings

Pankhurst et al. (2006) proposed that the genesis of these calc-alkaline high- $\mathrm{K}$ rocks was related to a crustal thickening in the upper plate that followed the ca 320-305 Ma continental collision of the Deseado Massif and the North Patagonian Massif. The high-K character should not be interpreted as indicating a particular tectonic environment, but rather as a product of the mineralogical and elementary content of mafic sources combined with different degrees of hybridization with felsic materials (e.g., mixing and mingling processes). A primary interpretation of the chemical and isotopic features of these rocks would be that the suitable protoliths for I-type granitic magmas could be related to a previous nearby subduction. Although the volume of mafic rocks within the age range of La Esperanza plutonic-volcanic complex related to the high-K rocks is not significant (e.g., mafic microgranular enclaves and basic dikes), mafic underplating could be invoked as a source of the heat responsible for the magma generation. An alternative process allowing heat in the lower crust is the juxtaposition of the asthenospheric mantle against the base of the crust (i.e. detachment of a subducting slab) and does not require a continental collision. An element that we should start looking at when further isotopic data becomes available is the Hf-isotopic compositions of the 
inherited zircons aged between 300 and $280 \mathrm{Ma}$. The $\varepsilon \mathrm{Hf}$ values of two zircon rims (inherited) aged 302 and $290 \mathrm{Ma}$ (grains 3.2 and 11.2 of Fanning et al., 2011) of the Calvo Granite (low crystallization $\mathrm{TZr} \approx 725 \mathrm{Ma}$ ) are -3.7 and -3.8 (recalculated after Fanning et al., 2011) whereas those of igneous zircon in the Prieto Granodiorite vary between -2.9 and -4.6 units. This suggests that zircons aged between 300 and $270 \mathrm{Ma}$ are showing magmas with more positive Hf signatures than those of the latest Permian. At this age, c. $300 \mathrm{Ma}$, massive diorite bodies were dated in the proto-Andean open margin of Gondwana at the same latitude of Estancia La Esperanza, such as the Rahue diorite (WR-mineral Rb-Sr composite isochrons $296 \pm 2 \mathrm{Ma}, 300 \pm 3 \mathrm{Ma}$; Lucassen et al., 2004) and, further west, the Coastal Batholith (Deckart et al., 2014). Whole-rock initial ${ }^{143} \mathrm{Nd} /{ }^{144} \mathrm{Nd}$ and zircon initial ${ }^{177} \mathrm{Hf} /{ }^{178} \mathrm{Hf}$ ratios also point towards a common origin for the Prieto Granodiorite and other older-than-260 Ma plutonic complexes such as Quintuleu Granodiorite in the Mamil Choique complex $(281 \pm 2 \mathrm{Ma}$; $-3.6<\varepsilon \mathrm{Hf}_{\mathrm{t}}<-4.2$, recalculated after Fanning et al., 2011) in the southwest of the North Patagonian Massif and the granodiorites of the Navarrete plutonic complex (282 $\pm 2 \mathrm{Ma}$, Pankhurst et al. (2006); $-3.5<\varepsilon \mathrm{Hf}_{\mathrm{t}}<2.9$, recalculated after Fanning et al. (2011); see discussion in Martínez Dopico et al. (2011, 2017a) and Castillo et al. (2017)) (Fig. 10). In turn, for the magmatism after $260 \mathrm{Ma}$ in La Esperanza area, represented by Donosa Granite, La Esperanza Monzogranite and Calvo Granite, isotope data show that the felsic component is higher in the magmatic precursors than those previously molten. The volume of this second stage is larger than the first and corresponds to a major tectonic change with respect to the older conditions. Recent dating and stratigraphic studies (Luppo et al., 2018, 2019) suggest that the plutonic-volcanic event in La Esperanza area is synchronous and geochemically comparable with the dacites, rhyolites and rhyolitic and dacitic ignimbrites represented by the northernmost expression of the Los Menucos Group (258-252 Ma) (Fig. 10). We propose that La Esperanza-Los Menucos magmatic system meets the criteria proposed by Bryan et al. (2002) to consider it as a "Silicic Large Igneous Province" (SLIP): 1) its bulk magmatism would have reached at least $4000 \mathrm{~km}^{2}$; 2) extrusive volumes are larger than $\left.8000 \mathrm{~km}^{3} ; 3\right)$ it is volumetrically dominated ( $>75 \%$ ) by dacite to rhyolite igneous rock that have calc-alkaline I-type signatures; 4 ) it is lithologically dominated by silicic ignimbrites; 5 ) igneous activity over long periods ( $>30 \mathrm{Ma}$ ); and 6) a spatial and temporal relationship to continental rifting, plate breakup and potentially, other mafic large igneous provinces. The La Esperanza-Los Menucos magmatic system is not only temporally related to the Choiyoi magmatic province in western Argentina (Strazzere et al., 2006; Kleiman and Japas, 2009; Rocha-Campos et al., 2011; Sato et al., 2015; Rocher et al., 2015), but also spatially associated with other late Permian to Triassic magmatic igneous complexes in Patagonia such as the Mamil Choique complex, Navarrete plutonic complex, Ramos Mejía and Yaminué igneous complexes (see Pankhurst et al., 2006, 2014; Martínez Dopico et al., 2011; 2017a). Further studies of the plutonic connections of the Choiyoi magmatic event and contemporaries should be focused on isotope, whole-rock and mineral geochemistry in order to understand the triggering factors for this regional magmatism.

\section{Final remarks}

La Esperanza plutonic-volcanic complex (LEPVC) and its temporallithological eruptive counterpart, the Los Menucos Group, meet the requirements for a Silicic Large Igneous Province (albeit rather smaller than most global examples) that is bracketed in age between 273 and $244 \mathrm{Ma}$. Several compositionally and isotopically distinct, high-K, magnesian, calc-alkaline series were distinguished: High Ba-Sr (i) metaluminous amphibole-biotite bearing granodiorites ( $273 \pm 2 \mathrm{Ma}$ ); (ii) biotite and muscovite-bearing rhyolites and granites $(265 \pm 2 \mathrm{Ma}$; $260 \pm 2 \mathrm{Ma}$ ) and (iv) and metaluminous mafic microgranular enclavebearing amphibole-biotite monzogranites (255 $\pm 2 \mathrm{Ma})$, dacites
(253 $\pm 2 \mathrm{Ma}$ ), and slightly peraluminous granites; and, finally, Low Ba-Sr high silica metaluminous rocks (granites and acid dike swarms $250 \pm 2 \mathrm{Ma}$ and $\approx 244 \pm 2 \mathrm{Ma}$ represented by the subvolcanic Calvo Granite and the acidic dike swarm. The episode of shallow intermediate to acidic granite magmatism in LEPVC is now dated with the new U-Pb SHRIMP zircon data for the Giménez Granite as old as $251 \pm 2 \mathrm{Ma}$. Geochemistry revealed a multi-sourced open magmatic system evidenced by rocks with very different major and trace element contents and initial $\mathrm{Sr}$ and $\mathrm{Nd}$ ratios at equivalent $\mathrm{SiO}_{2}$ intervals. The magmatic system underwent mafic magma replenishment (shown by the La Esperanza granodiorites and their mafic microgranular enclaves and the Collinao dacites) following an episode of crust-derived magmas represented by the Donosa granites and the Pailemán rhyolites. Available crystallization ages suggest the magmatism spanned in time over $30 \mathrm{Ma}$ with two magmatic lulls (Fig. 10) that coincided with exhumation in upper crustal levels.

The new temporal, lithological, isotopic and geochemical features allow correlation of the La Esperanza plutonic-volcanic complex with the Los Menucos Group, encompassing a volume of magmatism comparable to a small-sized Silicic Large Igneous Province (Fig. 10). The mid-late Permian to Middle Triassic rocks in northern Patagonia record a transition between subduction-related magmatism ( $>273 \mathrm{Ma}$ ) associated with mafic magmatic sources with limited interaction with a felsic component, to post-orogenic extensional, mostly felsic hybridized sources $(<260 \mathrm{Ma})$ in the Gondwana margin. Even though La Esperanza - Los Menucos magmatism would be coeval with the collision of the Patagonia terrane, syn-collisional magmatism or associated deformation were not found in upper crustal levels, as expected. However, the different nature and melting conditions of the inferred sources of the magmas that crystallized before $270 \mathrm{Ma}$, between 265 and $260 \mathrm{Ma}$, and from 255 to $245 \mathrm{Ma}$, suggest that the La Esperanza plutonic-volcanic complex was assembled during a $30 \mathrm{Ma}$ period of major plate reorganization.

\section{Acknowledgements}

This work was supported by the Agencia Nacional de Promoción Científica y Tecnológica (Argentina) under grants PICT2013-1162 and PICT2016-2188, PICT2016-3148. We thank an anonymous reviewer and R. Pankhurst for thorough and constructive reviews and A. Folguera for his editorial handling. C.I. Martínez Dopico would like to thank T. Luppo, G. Giordanengo, and Fundaleu (Fundación de Lucha contra la Leucemia).

\section{Appendix A. Supplementary data}

Supplementary data to this article can be found online at https:// doi.org/10.1016/j.jsames.2019.102347.

\section{References}

Bea, F., 1996. Residence of REE, Y, Th and U in granites and crustal protoliths; implications for the chemistry of crustal melts. J. Petrol. 37 (3), 521-552. https://doi. org/10.1093/petrology/37.3.521.

Black, L.P., Kamo, S.L., Allen, C.M., Aleinikoff, J.N., Davis, D.W., Korsch, R.J., Foudoulis, C., 2003. TEMORA 1: a new zircon standard for Phanerozoic U-Pb geochronology. Chem. Geol. 200, 155-170.

Bouvier, A., Vervoort, J.D., Parchett, P.J., 2008. The Lu-Hf and Sm-Nd isotopic composition of CHUR: constraints from unequilibrated chondrites and implications for the bulk composition of terrestrial planets. Earth Planet. Sci. Lett. 273, 48-57.

Boynton, N.V., 1984. Cosmochemistry of the rare earth elements: meteorite studies. En Rare Earth Element Geochemistry. In: Henderson, P. (Ed.), Development in Geochemistry. vol. 2. Elsevier, pp. 63-114.

Bryan, S.E., Riley, T.R., Jerram, D.A., Leat, P.T., Stephens, C.J., 2002. Silicic volcanism: an under-valued component of large igneous provinces and volcanic rifted margins. In: Menzies, M.A., Klemperer, S.L., Ebinger, C.J., Baker, J. (Eds.), Magmatic Rifted Margins. vol. 362. Geological Society of America Special Paper, pp. 99-120.

Caminos, R., Llambías, E.J., Rapela, C.W., Párica, C.A., 1988. Late Paleozoic-Early Triassic magmatic activity of Argentina and the significance of new Rb-Sr ages from northern Patagonia. J. South Am. Earth Sci. 1, 137-145. 
Castillo, P., Fanning, C.M., Pankhurst, R.J., Hervé, F., Rapela, C.W., 2017. Zircon O- and Hf-isotope constraints on the genesis and tectonic significance of Permian magmatism in Patagonia. J. Geol. Soc. 10 1144/jgs2016-152.

Chappell, B.W., White, A.J.R., 1983. Granitoid types and their distributions in the Lachlan Fold Belt, southeastern Australia. Geol. Soc. Am. Mem. 159, 21-34.

Chernicoff, C.J., Zappettini, E.O., Santos, J.O.S., Belousova, E., McNaughton, N.J., 2013. Combined U-Pb SHRIMP and Hf isotope study of the Late Paleozoic Yaminué Complex, Río Negro province, Argentina. Implications for the origin and evolution of the Patagonia composite terrane. Geosci. Front. 4 (6), 37-56.

Cingolani, C., Dalla Salda, L., Hervé, F., Munizaga, F., Pankhurst, R.J., Parada, M.A., Rapela, C.W., 1991. The magmatic evolution of northern Patagonia; New impressions of pre- andean tectonics. Geol. Soc. Am. Spec. Pap. 265, 29-43.

Clemens, J.D., Darbyshire, D.P.F., 2009. Sources of post-orogenic calcalkaline magmas: The Arrochar and Garabal Hill-Glen Fyne complexes, Scotland. Lithos 112, 524-542.

Clemens, J.D., Helps, P.A., Stevens, G., 2010. Chemical structure in granitic magmas - a signal from the source? Earth Env. Sci. Trans. R. Soc. Edinburgh 100 (1-2), 159-172. https://doi.org/10.1017/s1755691009016053.

Cucchi, R., Lema, H., Busteros, A., 2001. Hoja Geológica 4169-II, Los Menucos. Provincia de Río Negro. Instituto de Geología y Recursos Minerales, Servicio Geologico Minero Argentino. Boletín 265, 67pp. Buenos Aires.

Deckart, K., Hervé, F., Fanning, M., Ramírez, V., Calderón, Godoy, M., 2014. U-Pb geochronology and Hf-O isotopes of zircons from the Pennsylvanian coastal Batholith, south- Central Chile. Andean Geol. 41, 49-82. https://doi.org/10.5027/ andgeoV41n1-a03.

Fanning, C.M., Hervé, F., Pankhurst, R.J., Rapela, C.W., Kleiman, L.E., Yaxley, G.M., Castillo, P., 2011. Lu-Hf isotope evidence for the provenance of Permian detritus in accretionary complexes of western Patagonia and the northern Antarctic Peninsula region. J. South Am. Earth Sci. 32, 485-496.

Farina, F., Stevens, G., Gerdes, A., Frei, D., 2014. Small-scale Hf isotopic variability in the Peninsula pluton (South Africa): the processes that control inheritance of source 176Hf/177Hf diversity in S-type granites. Contrib. Mineral. Petrol. 168, 1065. https://doi.org/10.1007/s00410-014-1065-8.

Frost, B.R., Barnes, C.G., Collins, W.J., Arculus, R.J., Ellis, D.J., Frost, C.D., 2001. A geochemical classification for granitic rocks. J. Petrol. 42, 2033-2048.

Giacosa, R.E., Lema, H., Busteros, A., Zubia, M., Cucchi, R., Tommaso, D.I., 2007. Estructura del Triásico de la región norte Macizo Nordpatagónico $\left(40^{\circ}-41^{\circ} \mathrm{S}, 67^{\circ} 30^{\prime}\right.$ $69^{\circ} 45^{\prime}$ ) ) Río Negro. Rev. Asoc. Geol. Argent. 62 (3), 355-365.

González, S.N., Greco, G.A., Sato, A.M., Llambías, E.J., Basei, M.A.S., González, P.D., Días, P.E., 2017. Middle Triassic trachytic lava flows associated with coeval dyke swarm in the North Patagonian Massif: a postorogenic magmatism related to entensional collapse of the Gondwanide orogen. J. South Am. Earth Sci. 75, 134-143.

Pearce, J.A., Harris, N.W., Tindle, A.G., 1984. Trace element discrimination diagrams for the tectonic interpretation of granitic rocks. J. Petrol. 25, 956-983.

Harris, N.B.W., Pearce, J.A., Tindle, A.G., 1986. Geochemical characteristics of collisionzone magmatism. In: Coward, M.P., Ries, A.C. (Eds.), Collision Tectonics. vol. 19. Geological Society London Special Publication, pp. 67-81.

Janousek, V., Farrow, C.M., Erban, V., 2006. Interpretation of whole-rock geochemical data in igneous geochemistry: introducing Geochemical Data Toolkit (GCDkit). J. Petrol. 47 (6), 1255-1259. https://doi.org/10.1093/petrology/eg1013.

Janousek, V., Moyen, J.F., Martin, H., Erban, V., Farrow, C., 2016. Geochemical Modelling of Igneous Processes - Principles and Recipes in R Language. Bringing the Power of R to a Geochemical Community. Springer-Verlag, Berlin, Heidelberg, pp. $1-346$.

Kleiman, L.E., Japas, M.S., 2009. The Choiyoi volcanic province at $34^{\circ}-36^{\circ} \mathrm{S}$ (San Rafael, Mendoza, Argentina): implications for the late Paleozoic evolution of the southwestern margin of Gondwana. Tectonophysics 473, 283-299.

Labudía, C.H., Bjerg, E.A., 1994. Geología del Sector Oriental de la Hoja Bajo Hondo (39e), Provincia de Río Negro. Rev. Asoc. Geol. Argent. 49 (3/4), 284-296.

Llambías, E.J., Rapela, C.W., 1984. Geología de los complejos eruptivos del Paleozoico superior de La Esperanza, provincia de Río Negro. Rev. Asoc. Geol. Argent. 39 (3-4), 220-243.

Lucassen, F., Trumbull, R., Franz, G., Creixell, C., Vásquez, P., Romer, R.L., Figueroa, O., 2004. Distinguishing crustal recycling and juvenile additions at active continental margins: the Paleozoic to recent composition of the Chilean Pacific margin (36-41 $\mathrm{S}$ ). J. South Am. Earth Sci. 17, 103-119.

Ludwig, K.R., 2005. ISOPLOT/Ex A Geochronological Toolkit for Microsoft Excel Berkeley Geochronology Center Special Publication $N^{\circ} 1$ a, Berkeley.

Luppo, T., López de Luchi, M.G., Rapalini, A.E., Martínez Dopico and, C.I., Fanning, C.M., 2018. Geochronologic evidence of a large magmatic province in northern Patagonia encompassing the Permian-Triassic boundary. J. South Am. Earth Sci. 82, 346-355.

Luppo, T., Martínez Dopico, C.I., Rapalini, A.E., López de Luchi, M.G., Miguez, M., Fanning, C.M., 2019. Paleomagnetism of Permo-Triassic volcanic units in northern patagonia: are we tracking the final stages of collision of Patagonia? Int. J. Earth Sci. 108 (2), 621-647.

Maas, R., Kinny, P.D., Williams, I.S., Froude, D.O., Compston, W., 1992. The Earth's oldest known crust: A geochronological and geochemical study of 3900-4200 Ma detrital zircons from Mt Narryer and Jack Hills, Western Australia: Geochimica et Cosmochimica Acta. Geochim. Cosmochim. Acta 56, 1281-1300. https://doi.org/10. 1016/0016-7037(92)90062-N.

Martínez Dopico, C., López de Luchi, M., Rapalini, A.E., Hervé, F., Fuentes, F., Fanning, M., 2017. U-Pb SHRIMP Dating of Detrital Zircon Grains of the Colo Niyeu Formation: Extending the Neoproterozoic to Early Cambrian Basins to Central Western Northern Patagonia. XX Congreso Geológico Argentino, Tucumán, pp. 6.

Martínez Dopico, C., Lopez de Luchi, M., Rapalini, A.E., Kleinhanns, I.C., 2011. Crustal segments in the North Patagonian Massif, Patagonia: an integrated perspective based on Sm/Nd isotope systematics. J. South Am. Earth Sci. 31, 324-341.
Martínez Dopico, C.I., López de Luchi, M.G., Wemmer, K., Rapalini, A.E., 2013a. Composición química de biotita y hornblenda y edades de enfriamiento como indicadores de las condiciones de emplazamiento del Complejo Plutónico La Esperanza (Pérmico Superior), Macizo Norpatagónico. Rev. Asoc. Geol. Argent. 70, 3-15.

Martínez Dopico, C.I., Rapalini, A.E., López de Luchi, M.G., Wemmer, K., 2013b. Assembly of shallow intrusions from multiple magma pulses in La Esperanza plutonic complex, Northpatagonian Massif, Argentina. Latinmag Lett. 3 OB06, 5pp.

Martínez Dopico, C.I., López de Luchi, M.G., Rapalini, A.E., 2014. Geoquímica del Complejo Plutónico La Esperanza (Pérmico), Provincia de Río Negro. XIX Congreso Geológico Argentino.

Martínez Dopico, C.I., López de Luchi, M.G., Rapalini, A.E., Wemmer, K., Fanning, M., Basei, M., 2017a. Emplacement and temporal constraints of the gondwanan intrusive complexes of Northern Patagonia: La Esperanza plutono-volcanic case. Tectonophysics 712-713, 249-269. https://doi.org/10.1016/j.tecto.2017.05.015.

Martínez Dopico, C.I., Tohver, E., López de Luchi, M.G., Wemmer, K., Rapalini, A.E., Cawood, P.A., 2017b. Jurassic cooling ages in Paleozoic to early Mesozoic granitoids of northeastern Patagonia: 40Ar/39Ar, 40K-40Ar mica and U-Pb zircon evidence. Int. J. Earth Sci. https://doi.org/10.1007/s00531-016-1430-0.

Middlemost, E.A.K., 1994. Naming materials in the magma/igneous rock system. Earth Sci. Rev. 37, 215-224.

Ohta, T., Arai, H., 2007. Statistical empirical index of chemical weathering in igneous rocks. Chem. Geol. 18, 280-297.

Pankhurst, R.J., Rapela, C.W., Caminos, R., Llambías, E., Parica, C., 1992. A revised age for the granites of the central Somuncura Batholith, North Patagonian Massif. J. South Am. Earth Sci. 5 (3/4), 321-325.

Pankhurst, R.J., Rapela, C.W., Fanning, C.M., Márquez, M., 2006. Gondwanide continental collision and the origin of Patagonia. Earth Sci. Rev. 76, 235-257. https:// doi.org/10.1016/j.earscirev.2006.02.001.

Pankhurst, R.J., Rapela, C.W., Lopez De Luchi, M.G., Rapalini, A.E., Fanning, C.M., Galindo, C., 2014. The Gondwana connections of northern Patagonia. J. Geol. Soc. 171, 313e328. https://doi.org/10.1144/jgs2013-081.

Paterson, S.R., Vernon, R.H., Zak, J., 2005. Mechanical Instabilities and physical accumulation of K-feldspar megacrysts in granitic magma, Tuoumne Batholith, California, USA. J. Virtual Explor. 18, 1.

Pearce, J.A., 1996. Sources and settings of granitic rocks. Episodes 19 (4), 120-125.

Peccerillo, A., Taylor, S.R., 1976. Geochemistry of Eocene calc-alkaline volcanic rocks from the Kastamonu area, northern Turkey. Contrib. Mineral. Petrol. 58, 63-81. https://doi.org/10.1007/BF00384745.

Ramos, V.A., 1984. Patagonia: ¿Un continente paleozoico a la deriva? $9^{\circ}$ Congreso Geológico Argentino. San Carlos de Bariloche, Actas 2, 311-325.

Rapela, C.W., Llambías, E.J., 1985. Evolución magmática y relaciones regionales de los Complejos Eruptivos de La Esperanza, provincia de Río Negro. Rev. Asoc. Geol. Argent. 40 (1-2), 4-25.

Ridolfi, F., Renzulli, A., 2012. Calcic amphiboles in calc-alkaline and alkaline magmas: thermobarometric and chemometric empirical equations valid up to $1130{ }^{\circ} \mathrm{C}$ and 2.2 GPa. Contrib. Mineral. Petrol. 163, 877-895.

Ridolfi, F., Renzulli, A., Puerini, M., 2010. Stability and chemical equilibrium of amphibole in calc-alkaline magmas: an overview, new thermobarometric formulations and application to subduction-related volcanoes. Contrib. Mineral. Petrol. 160, 45-66.

Roberts, M., Clemens, J.D., 1993. Origin of high-potassium, calc-alkaline, I-type granitoids. Geology 21, 825-828.

Rocha-Campos, A.C., Basei, M.A., Nutman, A.P., Kleiman, L.E., Varela, R., Llambías, E., Canile, F.M., da Rosa, O., de, C.R., 2011. 30 million years of Permian volcanism recorded in the Choiyoi igneous province (W Argentina) and their source for younger ash fall deposits in the Paraná Basin: SHRIMP U-Pb zircón geochronology evidence. Gondwana Res. 19, 509-523.

Rocher, S., Vallecillos, G., Castro de Machuca, B., Alasino, P., 2015. El Grupo Choiyoi (Pérmico temprano-medio) en la Cordillera Frontal de Calingasta, San Juan, Argentina: volcanismo de arco asociado a extensión. Rev. Mex. Ciencias Geol. 32 (3) 451-432.

Rotenberg, E., Davis, D.W., Amelin, Y., Ghosh, S., Bergquist, B.A., 2012. Determination of the decay-constant of ${ }^{87} \mathrm{Rb}$ by laboratory accumulation of ${ }^{87} \mathrm{Sr}$. Geochem. Cosmochim. Acta 85, 41-57.

Sato, A.M., Llambías, E.J., Basei, M.A.S., Castro, C.A., 2015. Three stages in the Late Paleozoic to Triassic magmatism of southwestern Gondwana, and the relationships with the volcanogenic events in coeval basins. J. South Am. Earth Sci. 63, 48-69.

Solé, J., 2009. Determination of K-Ar ages in milligram samples using an infrared laser for argon extraction. Rapid Commun. Mass Spectrom. 23, 3579-3590. https://doi.org/ $10.1002 / \mathrm{rcm} .4280$.

Solé, J., Enrique, P., 2001. X-ray fluorescence analysis for the determination of potassium in small quantities of silicate minerals for K-Ar dating. Anal. Chim. Acta 440, 199-205. https://doi.org/10.1016/S0003-2670 (01)01060-1.

Strazzere, L., Gregori, D.A., Dristas, J.A., 2006. Genetic evolution of Permo Triassic volcaniclastic sequences at Uspallata, Mendoza Precordillera, Argentina. Gondwana Res. 9, 485-499.

Tarney, J., Jones, C.E., 1994. Trace element geochemistry of orogenic igneous rocks and crustal growth models. J. Geol. Soc. 151, 855-868.

Taylor, S.R., McLennan, S.M., 1995. The geochemical evolution of the continental crust. Rev. Geophys. 33, 241-265.

Tera, F., Wasserburg, G.J., 1972. U-Th-Pb systematics in three Apollo 14 basalts and the problem of initial $\mathrm{Pb}$ in lunar rocks. Earth Planet. Sci. Lett. 14, 281-304. https://doi. org $/ 10.1016 / 0012-821 \times(72) 90128-8$.

Valley, J.W., 2003. Oxygen isotopes in zircon- Reviews in Mineralogy and Geochemistry. 53 (1). https://doi.org/10.2113/0530343.

Villaros, A., Stevens, G., Moyen, J.-F., Buick, I.S., 2009. The trace element compositions of 
S-type granites: evidence for disequilibrium melting and accessory phase entrainment in the source. Contrib. Mineral. Petrol. 158 (4), 543-561.

Watson, E.B., Harrison, T.M., 1983. Zircon saturation revisited: temperature and composition effects in a variety of crustal magma types. Earth Planet. Sci. Lett. 64 295-304.
Williams, I.S., 1998. U-Th-Pb Geochronology by Ion Microprobe. In: en McKibben, M.A., Shanks IIIW.C., Ridley, W.I. (Eds.), Applications of Microanalytical Techniques to Understanding Mineralizing Processes: Littleton, Society of Economic Geologists. Reviews in Economic Geology. vol. 7. pp. 1-35. 